\title{
What can we learn about ship emission inventories from measurements of air pollutants over the Mediterranean Sea?
}

\author{
E. Marmer ${ }^{1}$, F. Dentener ${ }^{1}$, J. v. Aardenne ${ }^{1}$, F. Cavalli ${ }^{1}$, E. Vignati ${ }^{1}$, K. Velchev ${ }^{1}$, J. Hjorth ${ }^{1}$, F. Boersma ${ }^{2}$, G. Vinken $^{3}$, \\ N. Mihalopoulos ${ }^{4}$, and F. Raes ${ }^{1}$ \\ ${ }^{1}$ European Commission, Joint Research Centre, Institute of Environment and Sustainability, via E. Fermi, 2749, \\ 21027 Ispra, Italy \\ ${ }^{2}$ KNMI, Climate Observations Department, Wilhelminalaan 10, 3732 GK De Bilt, The Netherlands \\ ${ }^{3}$ Eindhoven University of Techology, Den Dolech 2, 5612 AZ Eindhoven, The Netherlands \\ ${ }^{4}$ University of Crete, Department of Chemistry, 71003 Heraklion, Greece
}

Received: 6 February 2009 - Published in Atmos. Chem. Phys. Discuss.: 17 March 2009

Revised: 27 May 2009 - Accepted: 1 September 2009 - Published: 18 September 2009

\begin{abstract}
Ship emission estimates diverge widely for all chemical compounds for several reasons: use of different methodologies (bottom-up or top-down), activity data and emission factors can easily result in a difference ranging from a factor of 1.5 to even an order of magnitude. Combining three sets of observational data - ozone and black carbon measurements sampled at three coastal sites and on board of a Mediterranean cruise ship, as well as satellite observations of atmospheric $\mathrm{NO}_{2}$ column concentration over the same area - we assess the accuracy of the three most commonly used ship emission inventories, EDGAR FT (Olivier et al., 2005), emissions described by Eyring et al. (2005) and emissions reported by EMEP (Vestreng et al., 2007). Our tool is a global atmospheric chemistry transport model which simulates the chemical state of the Mediterranean atmosphere applying different ship emission inventories. The simulated contributions of ships to air pollutant levels in the Mediterranean atmosphere are significant but strongly depend on the inventory applied. Close to the major shipping routes relative contributions vary from 10 to $50 \%$ for black carbon and from 2 to $12 \%$ for ozone in the surface layer, as well as from 5 to $20 \%$ for nitrogen dioxide atmospheric column burden. The relative contributions are still significant over the North African coast, but less so over the South European coast because densely populated regions with significant human activity contribute relatively more to air pollution than ships, even if these regions attract a lot of ship traffic. The observations poorly constrain the ship emission inventories in the Eastern Mediterranean where the influence of uncertain land
\end{abstract}

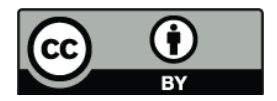

Correspondence to: E. Marmer (elinamar@gmx.net) based emissions, the model transport and wet deposition are at least as important as the signal from ships. In the Western Mediterranean, the regional EMEP emission inventory gives the best match with most measurements, followed by Eyring for $\mathrm{NO}_{2}$ and ozone and by EDGAR for black carbon. Given the uncertainty of the measurements and the model, each of the three emission inventories could actually be right, implying that large uncertainties in ship emissions need to be considered for future scenario analysis.

\section{Introduction}

Ship emissions and their impacts on environment became a "hot" issue in the past decade for atmospheric research and air pollution and climate policy. Recent publications on health impacts of particles emitted by ships (Corbett et al., 2007a), acidification and eutrofication of water and soil in coastal regions caused by sulfur and nitrogen deposition (Derwent at al., 2005), climate cooling owing to the high sulfur content of marine fuel (Devasthale et al., 2006; Lauer et al., 2007), climate warming caused by the emissions of GHGs (Stern, 2007) and absorbing black carbon (Lack et al., 2009), to name just a few, contributed to our knowledge of present environmental impacts of this steadily growing emission source. They also raised public awareness and put a growing pressure on policy makers to find an international agreement on ship emission regulations, as ship emissions are known to be one of the least regulated anthropogenic sources (Eyring et al., 2005). In Europe, where the land based emissions of sulfur have been successfully reduced since 1980 's, the ships are the only growing source of sul-

Published by Copernicus Publications on behalf of the European Geosciences Union. 
fur emissions. Unless more action is taken, by the year 2020 sulfur and nitrogen emissions from ships threaten to exceed all European land sources combined (CAFE, 2005), with a similar situation in the USA (ARB, 2006). International shipping is a major source of sulfur emissions in Asia because the rapid growth of Asian economies results in a corresponding growth of shipping trade (Streets et al., 1997, 2003). Last year, the International Maritime Organization (IMO) unanimously adopted amendments to the MARPOL Annex VI regulations to reduce $\mathrm{SO}_{\mathrm{x}}, \mathrm{NO}_{\mathrm{x}}$ and particulate emissions from ships (IMO, 2008). The revised Annex VI will enter into force in July 2010, the emission reduction measures will be phased in over the following decade. In support of the policy, research is required to investigate how the implementation of these regulations, combined with the predicted future growth of ship traffic and the geographical expansion of waterways and ports are going to affect the atmospheric composition. Several future emission scenarios have recently been developed (i.e. Granier et al., 2006; Eyring et al., 2007; Cofala et al., 2007). Starting point for these scenarios are various global and regional emission inventories, which largely differ in their ship emission estimates in total and for different compounds. These differences are caused by different methodologies as well as uncertainties in the emission factors. For instance, European inventories tend to give a higher estimate for the European regions than the global inventories (Wang et al., 2008), mainly because domestic shipping is not represented in the activity data on which the global inventories are based. Verification of the consistency of ship emissions inventories with observations is a difficult task due to lack of observations over the open sea. Cabaldo et al. (1999), Davis et al. (2001), Lawrence and Crutzen (1999) and Kasibhatla et al. (2000) have included ship emissions of $\mathrm{SO}_{2}$ and/or $\mathrm{NO}_{\mathrm{x}}$ into global atmospheric models to evaluate them with aircraft measurements over the Pacific and the North Atlantic. While including $\mathrm{SO}_{2}$ from ships have improved the model performance with respect to the observations, ship emissions of $\mathrm{NO}_{\mathrm{x}}$ seemed to be overestimated. Beirle et al. (2004) have quantified shipping emissions of $\mathrm{NO}_{\mathrm{x}}$ over the shipping route connecting Sri Lanka and Indonesia using GOME satellite data. Data from SCIAMACY, a remote sensing instrument with finer resolution, was used to verify ship emission estimates over the Red Sea by Richter et al. (2004). Both studies found a good agreement for $\mathrm{NO}_{\mathrm{x}}$ with existing inventories in the respective regions. Franke et al. (2008) combined data from both instruments in the Indian Ocean to verify all published $\mathrm{NO}_{\mathrm{x}}$ ship emission inventories and found the best agreement with the highest estimates.

We evaluate three widely used ship emission inventories EDGAR FT 2000 (Olivier et al., 2005), Eyring et al. (2005) and EMEP (Vestreng et al., 2007) - by implementing them in a chemistry transport model TM5 (Krol et al., 2005) and comparing the results with available observations. Our focus is on the Mediterranean Sea, first of all because its atmosphere appears to be one of the most polluted in the world
(Kouvarakis et al., 2000; Lelieveld and Dentener, 2000) and significant contribution of the very dense ship traffic connecting the Atlantic and the Indian Oceans is to be expected. Inland seas with intense transit and local ship traffic and high population density are especially affected by ship emissions, as found i.e. over the Mediterranean (Marmer and Langmann, 2005) and the Marmara Sea (Deniz and Durmusoĝlu, 2008). The second not less important reason is the fact that here we have a unique set of observational data from continuous on-board ship measurements (Velchev et al., 2009). In addition, the observations obtained from the OMI satellite over this area are for the first time used to constrain ship emissions.

Finally we present a new global ship emission inventory EDGARv4 aimed to consolidate the advantages and disadvantages of the regional and global inventories.

\section{Ship emission inventories}

We have examined six different ship emission inventories focusing on the Mediterranean Sea (Fig. 1), before choosing three of them for closer evaluation. All inventories include the emissions of nitrogen oxides $\left(\mathrm{NO}_{\mathrm{x}}\right)$, sulfur oxides $\left(\mathrm{SO}_{\mathrm{x}}\right)$, carbon oxide $(\mathrm{CO})$ and non methane volatile organic compounds (NMVOCs). While in global inventories carbonaceous particles such as black and organic carbon (BC and OC) are included explicitly, the regional inventories give the particulate emissions as $\mathrm{PM}_{2.5}$ (Table 1). For this study we have applied the speciation based on Anersson-Skøld and Simpson (2001), attributing $40 \%$ of the total $\mathrm{PM}_{2.5}$ to OC and $20 \%$ to BC (the remaining $40 \%$ assumed to be inorganics). This speciation varies across the literature, from $11 \%$ OC and 5\% BC (Eyring et al., 2005) over 30\% OC and 15\% BC (Lack et al., 2009) to 49\% OM and 6\% BC (Wang et al., 2008).

The global emission inventories EDGAR FT 2000 (Olivier et al., 2005, with OC and BC emissions based on Bond et al., 2004), later referred to as EDGAR, and Eyring et al. (2005), later referred to as Eyring, both compiled for the year 2000, are available on a $1^{\circ} \times 1^{\circ}$ horizontal resolution and their spatial distribution is based on AMVER data (Endresen et al., 2003). Despite the same resolution and spatial patterns, there is a large disagreement in terms of the emission totals in the Mediterranean Sea (Table 1). $\mathrm{SO}_{\mathrm{x}}$ and $\mathrm{NO}_{\mathrm{x}}$ emissions reported by Eyring are a factor of 1.6 and 2.2 higher than in EDGAR, respectively. This difference can be explained by the difference in the methodology (see Appendix A) in EDGAR a top-down approach is applied, which is based on bunker fuel statistics from International Energy Agency (IEA); Eyring et al. (2005) have applied the so called activity based top-down approach which is based on the information on ships and engine types (Lloyd's Register of Shipping, 2002). This activity based top-down approach results in higher emission estimate for $\mathrm{SO}_{\mathrm{x}}$ and $\mathrm{NO}_{\mathrm{x}}$. 


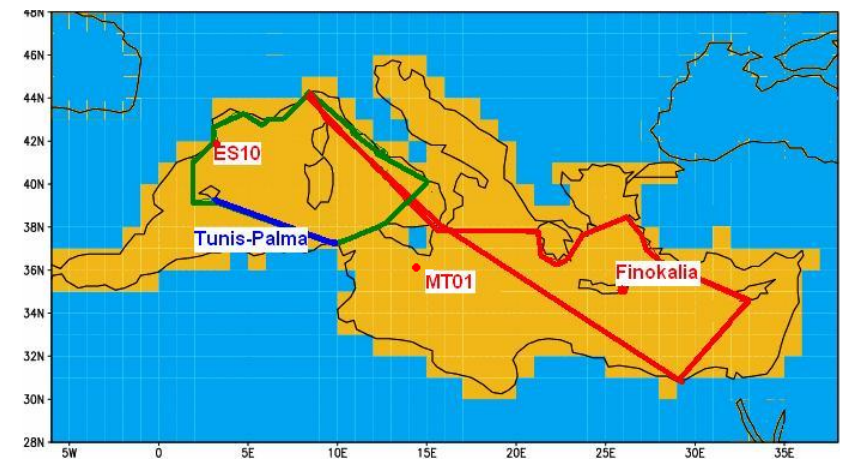

Fig. 1. The Mediterranean Sea in the model resolution is indicated yellow. Green line indicates Western Cruises (April-October 2006, 26 cruises). Blue line indicates the Tunis-Palma leg. Red line indicates Eastern Cruises (January-March 2006, 3 cruises). Three observational sites ES10 (Cabo de Creus, Spain, 42.3 N, 3.3 E), MT01 (Giordan Lighthouse, Malta, 36.1 N, 14.2 E) and Finokalia (Greece, $35.3 \mathrm{~N}, 25.7 \mathrm{E})$.

On the contrary, EDGAR reports higher values than Eyring for black carbon. The averaged emission factor for black carbon in EDGAR is $1.02 \mathrm{~g} \mathrm{~kg}^{-1}$ and is based on Bond et al. (2004). In Eyring et al. (2005), this emission factor is given as $0.18 \mathrm{~g} \mathrm{~kg}^{-1}$ and is based on Sinha et al. (2003). In the regional inventory EMEP (Vestreng et al., 2007) with twice as much $B C$ as in EDGAR, the emission factors are given as a range from $0.18 \mathrm{~g} \mathrm{~kg}^{-1}$ to $1.1 \mathrm{~g} \mathrm{~kg}^{-1}$ depending on the fuel type, getting closer to the recently obtained emission factors ranging from $0.36( \pm 0.23) \mathrm{g} \mathrm{kg}^{-1}$ to $0.97( \pm 0.66) \mathrm{g} \mathrm{kg}^{-1}$ for different vessel types (Lack et al., 2008). In Eyring and EMEP ca. 2 times more OC than BC is emitted (please note that in EMEP we artificially partition $\mathrm{PM}_{2.5}$ in $20 \% \mathrm{BC}$ and $40 \%$ OC). In EDGAR, on the contrary, the $\mathrm{OC}$ emissions make $1 / 3$ of the $\mathrm{BC}$ emissions.

The regional European inventories, ENTEC (Whall et al., 2002), EMEP (Vestreng et al., 2007), CONCAWE (2007) and IIASA (Cofala et al., 2007), all share the same spatial distribution and the same methodology and hence deliver comparable emission estimates for all compounds. The methodology applied here is a bottom-up approach and it is based on the distance each ship covers, the information provided by the Lloyd's Intelligence Unit (LMIU, 2004). Regional inventories give a much higher emission estimate for the Mediterranean Sea for all compounds (except NMVOCs) as compared to the global inventories not only because of different methodologies but also due to the inclusion of domestic shipping in the regional inventories (Wang et al., 2008). The ship emissions of NMVOC are most uncertain. In EDGAR a very low NMVOC emission factor has been assumed (Appendix A) resulting in two orders of magnitude lower emissions as compared to all the other inventories. Only in Eyring the evaporation of hydrocarbons during loading and handling has been considered, making some $50 \%$ of
Table 1. Ship emissions for the Mediterranean Sea from different inventories.

\begin{tabular}{llllllll}
\hline $\mathrm{Tg} / \mathrm{yr}$ & $\begin{array}{l}\text { EDGAR FT } \\
2000\end{array}$ & \multicolumn{2}{c}{$\begin{array}{c}\text { EDGARv4 } \\
2000\end{array}$} & $\begin{array}{l}\text { EYRING } \\
2000\end{array}$ & $\begin{array}{l}\text { EMEP } \\
2004\end{array}$ & $\begin{array}{l}\text { IIASA } \\
2000\end{array}$ & $\begin{array}{l}\text { CONCAWE } \\
2005\end{array}$ \\
& & int & total & & & & \\
\hline $\mathrm{SO}_{2}$ & 0.309 & 0.380 & 0.470 & 0.492 & 1.199 & 1.280 & 0.826 \\
$\mathrm{NO}_{\mathrm{x}}$ & 0.406 & 0.626 & 0.760 & 0.902 & 1.745 & 1.820 & 1.448 \\
$\mathrm{NMVOC}$ & 0.0008 & 0.020 & 0.024 & 0.130 & 0.058 & 0.0620 & 0.0510 \\
$\mathrm{BC}$ & 0.012 & 0.0015 & 0.0018 & 0.002 & 0.027 & n.s. & n.s. \\
$\mathrm{OC}$ & 0.0038 & 0.005 & 0.006 & 0.0056 & 0.053 & n.s. & n.s. \\
$\mathrm{PM}_{2.5}$ & n.s. & n.s. & n.s. & n.s. & 0.132 & n.s. & 0.091 \\
\hline
\end{tabular}

the total NMVOC emissions, which explains the difference between Eyring and all regional inventories.

One of the main advantages of the global inventories is their global coverage. Furthermore, the top-down approach used for global inventories allows a much faster emission calculation than the more detailed hence time consuming bottom-up approach used by the regional inventories. On the other hand, the resolution of the regional inventories is usually finer and their spatial distribution much more accurate. Since international fuel statistics do not include the fuel consumed for domestic ship traffic - from harbor to harbor within the same country - it has not been represented by the global inventories. The domestic ship traffic can be significant for the inland seas like the Mediterranean, which is surrounded by 22 countries. Applying bottom-up approach on a global scale would not only be much too costly, but would also be limited by the global unavailability of detailed ship movement data.

In order to consolidate the advantages of global and regional inventories, a new EDGAR version 4 (EDGARv4) global emission inventory has been compiled. It is using topdown approach like all the previous versions of EDGAR, but the calculation takes into account 15 different vessel types and distinguishes between harbor and sea activities. Furthermore, it combines AMVER and ICOADS ship activity data sets (Wang et al., 2008) largely improving the spatial resolution from $1^{\circ} \times 1^{\circ}$ to $0.1^{\circ} \times 0.1^{\circ}$. Additionally to the international fuel statistics, the national fuel data is used to account for the domestic ship traffic, its contribution ranging from $17-27 \%$ of total emissions, depending of different assumptions (Appendix A).

In all investigated inventories a temporally constant emission flux was assumed, i.e. the emissions are constant throughout the year. More details on methodology, distribution and coverage of different inventories can be found in Appendix A. 


\section{Modeling set-up}

\subsection{Ship emissions}

For the model simulations in this study we have implemented the two global inventories (EDGAR and Eyring) and one regional inventory (EMEP) embedded into EDGAR on the global scale, to simulate the contribution of ship emissions to air pollution, attempting to evaluate the inventories by comparing the simulated ozone and black carbon surface concentrations with measurements sampled on-board a cruise ship and at three coastal sites, and the simulated atmospheric $\mathrm{NO}_{2}$ columns with those obtained from satellite data. For a more detailed evaluation we have separated the Mediterranean in 2 regions - the Eastern Mediterranean, referred to as EM ( $6 \mathrm{~W}$ to $15 \mathrm{E}$ ) and the Western Mediterranean, referred to as $\mathrm{WM}$ (16 E to $36 \mathrm{E})$. For the substances analyzed in this work, the $\mathrm{NO}_{\mathrm{x}}, \mathrm{NMVOCs}$ and $\mathrm{BC}$, the emissions for these areas are shown in Table 2. It should be noticed, that the EastWest distribution in EDGAR and Eyring is nearly 40/60 for all compounds, while in EMEP it is close to 50/50. This discrepancy is probably due to the domestic shipping which is not considered in the global inventories and according to EMEP predominates in the Eastern part.

\subsection{Other emissions}

Only ship emissions have been varied in the different model runs, all other emissions - natural and anthropogenic - have been kept unchanged. The emissions are summarized in Appendix B.

\subsection{Chemistry transport model TM5}

The TM5 is an off-line global transport chemistry model (Krol et al., 2005) and is driven by ECMWF ERA-40 reanalysis meteorological data. It has a spatial global resolution of $6^{\circ} \times 4^{\circ}$ and a two-way zooming algorithm that allows regions to be resolved at a finer resolution of $1^{\circ} \times 1^{\circ}$. To smooth the transition between the global $6^{\circ} \times 4^{\circ}$ region and the regional $1^{\circ} \times 1^{\circ}$ domain (Mediterranean Sea in the present application), a domain with a $3^{\circ} \times 2^{\circ}$ resolution (Northern Hemisphere in the present application) has been added. In the current version, the model has a vertical resolution of 34 layers, defined in a hybrid sigma-pressure coordinate system with a higher resolution in the boundary layer and around the tropopause. The height of the first layer is approximately $50 \mathrm{~m}$.

The model transport has been extensively validated using ${ }^{222} \mathrm{Rn}$ and SF6 (Peters at al., 2004; Krol et al., 2005) and further validation was performed within the EVERGREEN Project (Bergamaschi et al., 2006). TM5 has participated in a number of recent global model comparisons, such as PhotoComp (Dentener et al., 2006; Stevenson et al., 2006) and AEROCOM (Kinne et al., 2006; Textor et al., 2006). TM5
Table 2. Ship emissions in the Western (from $6 \mathrm{~W}$ to $15 \mathrm{E}$ ) and the Eastern (from 16E to $36 \mathrm{E}$ ) Mediterranean.

\begin{tabular}{lcccccc}
\hline & \multicolumn{2}{c}{ EDGAR FT } & \multicolumn{2}{c}{ EYRING } & \multicolumn{2}{c}{ EMEP } \\
$\begin{array}{lcccccc}\text { Emissions } \\
{[\mathrm{Tg} / \mathrm{yr}]}\end{array}$ & WEST & EAST & WEST & EAST & WEST & EAST \\
\hline $\mathrm{NO}_{\mathrm{x}}$ & 0.229 & 0.177 & 0.509 & 0.393 & 0.938 & 0.806 \\
$\mathrm{NMVOC}$ & 0.0004 & 0.0003 & 0.077 & 0.053 & 0.030 & 0.026 \\
$\mathrm{BC}$ & 0.007 & 0.005 & 0.0012 & 0.0009 & 0.0142 & 0.0123 \\
\hline
\end{tabular}

generally performed among the better global models regarding ozone and oxidized nitrogen depositions, probably due to its relatively fine horizontal resolution. TM5 also participated in the recent regional EURODELTA exercise and was found to perform reasonably well with regard to ozone surface concentrations in Europe, with high correlations in summer and winter (van Loon et al., 2004). A good agreement of simulated surface $\mathrm{NO}_{\mathrm{x}}$ with EMEP measurements in winter and summer was found by de Meij at al. (2006) while black carbon was found to be underestimated by the model especially during winter by a factor 2.5 on average.

Gas phase chemistry is calculated using the CBM-IV chemical mechanism (Gery et al., 1989a,b) modified by Howeling et al. (1998), solved by means of the EBI method (Hertel et al., 1993). Dry deposition is calculated using the ECMWF surface characteristics and the resistance method (Ganzeveld and Lelieveld, 1995).

The aerosol compounds are considered only by mass and include sulfate, nitrate and ammonium, black and organic carbon, sea salt and dust. Black carbon is assumed to reside in the accumulation mode with a mass mean radius of $0.14 \mu \mathrm{m}$ for wet and dry removal. In cloud-free model gridcells BC is considered hydrophobic and does not take up water. In grid-cells containing clouds a constant interstitial mass fraction is assumed and the rest is scavenged with the same efficiency as sulfate.

We have performed six different model simulations (Table 3) for the meteorological year 2006. In each simulation, all land based emissions have been kept unchanged (see Sect. 3.2). In order to calculate the impact of ship emissions on the atmospheric concentration, we have performed a simulation which did not include any ship emissions at all; this experiment is referred to as NON. Two global ship emission inventories have been implemented, EDGAR FT 2000 - the simulation referred to as EDG - and Eyring - the simulation referred to as EYR. The regional EMEP ship emission inventory was selected for the forth experiment. Since we run our model on a global scale, this inventory was embedded into the global EDGAR ship emission inventory. We refer to this experiment as to EMEDG. In order to analyze the role of NMVOC from ships for the surface ozone formation, we have run a sensitivity study with the same ship emis- 
Table 3. Input to the various model runs.

\begin{tabular}{ll}
\hline NON & $\begin{array}{l}\text { No ship emissions } \\
\text { EDG }\end{array}$ \\
EDGAR FT 2000 (Olivier et al., 2005) \\
for the year 2000 \\
Eyring et al. (2005) \\
for the year 2000 \\
EMEP ship emissions for Europe \\
for the year 2004 (Vestreng et al., 2007) \\
globally embedded in EDGAR FT 2000 \\
like EMEDG but no \\
NMVOCs released from ships \\
like EMEDG but ship emissions \\
released between 30-100 m \\
EMEDG_H
\end{tabular}

sions as in EMEDG for all species but without any NMVOCs released from ships. This sensitivity experiment is referred to as EMEDG-noVOC. In all experiments described above, ship emissions have been released into the first vertical model layer and distributed between $0-30 \mathrm{~m}$, while in real world ship stacks can reach as high as $50 \mathrm{~m}$. In the EMEDG_H experiment we have tested the sensitivity towards the emission height by distributing all ship emissions between 30 and $100 \mathrm{~m}$ above surface. The global emission inventories refer to the year 2000, EMEP refers to the year 2004, while the model simulations represent the year 2006. With an annual growth rate of 2.5\% (Endresen et al., 2003), 16\% more ship emissions would be released for EDGAR and Eyring, and $5 \%$ for EMEP in 2006. The resulting surface concentrations for $\mathrm{BC}$ and $\mathrm{NO}_{2}$ can be easily calculated, but not for ozone due to non-linearity (see Sect. 4.2). This assumption would result in a $1.2 \%$ higher $\mathrm{BC}$ concentration for the EMEDG simulation, $1.3 \%$ for EDG and $0.4 \%$ for EYR. For $\mathrm{NO}_{2}$, the concentration would increase by $2.2 \%$ for the EMEDG simulation, by $2.4 \%$ for EDG and by $5 \%$ for EYR. We did not correct for these differences but they will not affect the conclusions drawn below.

\section{Observations}

\subsection{On-board ship observations}

A set of monitoring instruments has been installed on board of a Mediterranean cruise ship Costa Fortuna with regular weekly routes in the Western Mediterranean during late spring, summer and fall and in the Eastern Mediterranean during winter (Velchev et al., 2009, and Fig. 1). This campaign was launched in fall 2005 and is still on-going. Measurements of ozone, black carbon and the aerosol size distribution are performed every $10 \mathrm{~min}$ and the meteorological data are logged every $15 \mathrm{~min}$.
The instruments are placed in a cabin at the front of the ship, $47 \mathrm{~m}$ above sea-level. Ozone is measured by a Thermo $\mathrm{C} 49$ ozone analyzer, equivalent $\mathrm{BC}$ was measured by a 2-wavelength aethalometer from Magee Scientific (model $\mathrm{AE} 21$ ). The stated precision of the ozone analyzer is $1 \mathrm{ppbv}$, the observed zero-drift between calibrations was $1 \mathrm{ppbv}$ and the span-drift was between 0 and 3\%. Thus for the ozone concentrations measured over the Mediterranean Sea the typical uncertainty is approximately 2 ppbv.

While the aethalometer measures black carbon as the attenuation of light divided by an absorption cross section, the source characterization studies that form the basis of the emission inventories mainly rely on determinations of "elemental carbon" (Bond et al., 2004). Elemental carbon is determined by a thermo-optical method and defined operationally. Several studies show close to linear correlations between black carbon and elemental carbon concentrations, however the proportionally factor shows large variations between different sampling sites (Jeong et al., 2004). The aethalometer measurements of $\mathrm{BC}$ on Costa Fortuna were carried out using the value of the absorption cross section provided by the manufacturer; the method was compared to thermo-optical determinations of elemental carbon during two campaigns; for aerosols over the sea, the methods were found to agree within a range of $25 \%$.

The aethalometer being an optical method has the disadvantage, that other absorbing material than black carbon, such as mineral dust, can contaminate the measurements. To filter our data from the suspected dust contamination we used a method described by Cavalli et al. (2009). Most dust events took place during winter months when the ship has been on cruise in the Eastern Mediterranean. This finding can be confirmed by the results from satellite observations (Papadimas at al., 2008) showing high frequency of dust events in the Eastern Mediterranean during winter.

Meteorological data (surface pressure and air temperature) were provided from the automatic measurement station on the ship. Information on the position, speed and direction of the ship were available, identifying situations where contamination from the emissions of the ship itself might interfere with the measurements.

The cruise ship is mostly sailing during the evening/night and stays in harbors during the day; exceptions are the routes Tunis-Palma and Alexandria-Messina, where both day and night hours are included. For our purpose we only consider the open sea measurements removing the data collected in harbors from $2 \mathrm{~h}$ prior to arrival to $2 \mathrm{~h}$ after the departure.

The TM5 model samples ozone, black carbon and the meteorological data every $30 \mathrm{~min}$ simultaneously with the cruise ship. We have compared the ozone and black carbon measurements separately averaged over all Eastern and all Western cruises with the model results from each of the experiments. 


\subsection{Satellite measurements}

The OMI instrument is a nadir viewing imaging spectrograph that measures the solar radiation backscattered by the Earth's atmosphere and surface over the entire wavelength range from 270 to $500 \mathrm{~nm}$ with a spectral resolution of about $0.5 \mathrm{~nm}$. The $114^{\circ}$ viewing angle of the telescope corresponds to a $2600 \mathrm{~km}$ wide swath on the surface, which enables measurements with a daily global coverage (Boersma et al., 2007). The error of a single OMI retrieval is best referred to as $1.0 \times 10^{15}$ molecules $\mathrm{cm}^{-2}+30 \%$, for detailed error analysis please see Boersma et al. (2004, 2007). The TM5 has sampled the $\mathrm{NO}_{2}$ atmospheric column simultaneously with the satellite overpass at 13:30 LT. The OMI pixels (from $13 \times 24 \mathrm{~km}^{2}$ in nadir up to $26 \times 135 \mathrm{~km}^{2}$ at the edges of the swath) have been interpolated to the $1^{\circ} \times 1^{\circ}$ grid, requiring at least $50 \%$ of the grid to be covered by OMI data. The grid boxes not meeting this criterion were marked as cloudy and filtered. The same grid boxes were also filtered from the TM5 samples as well to assure better comparability. Thus if OMI has seen more than $50 \%$ of the grid box as "cloudy", this grid box has been excluded from the evaluation, because the clouds screen the $\mathrm{NO}_{2}$ below, which can not be retrieved. Here we focus on summertime observations, when cloud free conditions prevail. Each grid cell contains 500 to 1000 cloud-free OMI pixels thus the random error is significantly reduced by the spatial averaging. The monthly mean $\mathrm{NO}_{2}$ columns for June, July and August 2006 resulting from the experiments NON, EDG, EYR and EMEDG have been compared with satellite measurements.

\section{Results}

All comparisons with observational data show that the TM5 model can simulate the level of air pollutants over the Mediterranean Sea reasonably well.

\subsection{Black carbon}

In this version of TM5 black carbon is treated as bulk mass, e.g. we do not consider particle size and number distribution. Black carbon does not participate in chemical reactions, once emitted it is advected by turbulence and large scale eddies and is removed by dry and wet deposition, thus acting as a passive tracer. Therefore we expect a linear model response of black carbon surface concentration to varying emissions (Fig. 2). Releasing the emissions at higher levels $30-100 \mathrm{~m}$ as in the experiment EMEDG-H rather than 0-30 m reduces the mean surface concentration by $3.6 \%$. This difference is slightly larger in summer with relatively stable atmospheric conditions (WM cruises) than in winter (EM cruises). The relative contribution of ship emissions to the surface $\mathrm{BC}$ also varies quite significantly for different emission inventories. In EYR, the simulation with lowest BC emissions, this contribution is limited to the Western part close to the main ship-

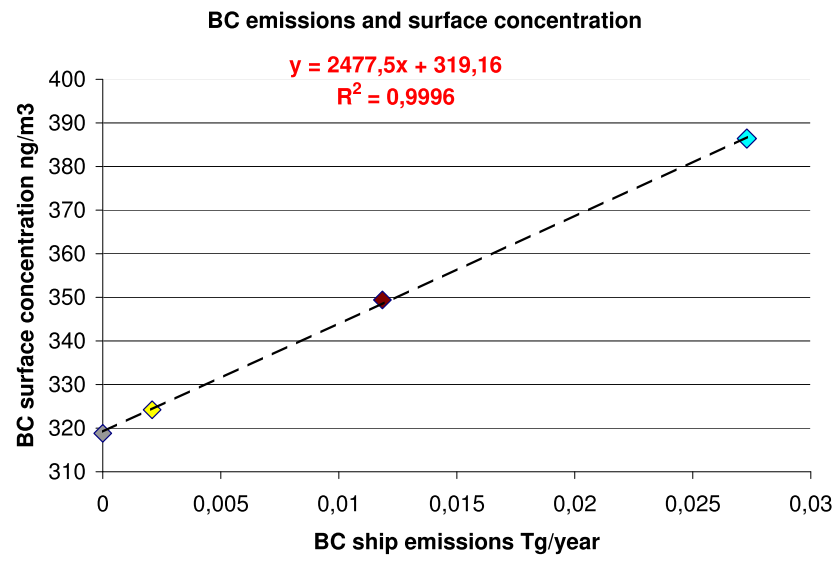

Fig. 2. BC ship emissions and the mean modeled 2006 BC surface concentration over the Mediterranean Sea. Grey NON, yellow EYR, brown EDG, light blue EMEDG, and dark blue EMEDG-H.

ping route and does not exceed 10\% (Fig. 3). In EMEDG, the simulation with highest $\mathrm{BC}$ emissions, the contribution is $35-50 \%$ close to the main shipping routes in the Eastern and the Western part, about $15-25 \%$ over large distances over the North African coast during summer, while at the Southern European coast the contribution is less than $15 \%$. Comparison of the mean measurements obtained during all Eastern and all Western cruises with the mean of simultaneously sampled model BC concentrations shows a slight overestimation of the simulated BC of the cruises in the WM (April to October, Table 4). Even the simulation without ships gives a higher BC concentration than the observed one. which seems to be related to the uncertainty of land based emissions of black carbon, typically a factor of 2 (Bond et al., 2004). If we look separately at the results for the leg Tunis-Palma de Mallorca (TP, Fig. 1), which crosses the highly frequented shipping route at $37 \mathrm{~N}$, the agreement largely improves and we find the best agreement with EMEDG (Table 4). In vicinity of the emission sources, the properties of black carbon correspond better to those assigned to it in the model, before internal mixing with other particles and aging can have an affect on its hydroscopicity and wet deposition. The underprediction of BC during the EM winter cruises (January to March) could result from too high deposition of $\mathrm{BC}$ in the model. There is a pronounced annual cycle in the simulated BC surface concentration with a maximum in July and a minimum in March. To a great extend the annual cycle in the model is driven by precipitation and wet deposition of BC (Fig. 4). It is difficult to conclude about the $\mathrm{BC}$ annual cycle over the Mediterranean based on the on-board measurements, since the ship travels in different regions during the different seasons, but from the BC measured at Finokalia, a site on Crete Island in the Eastern Mediterranean, no pronounced annual cycle could be detected. A comparison of BC observations at this site with model simulations shows that during winter, 

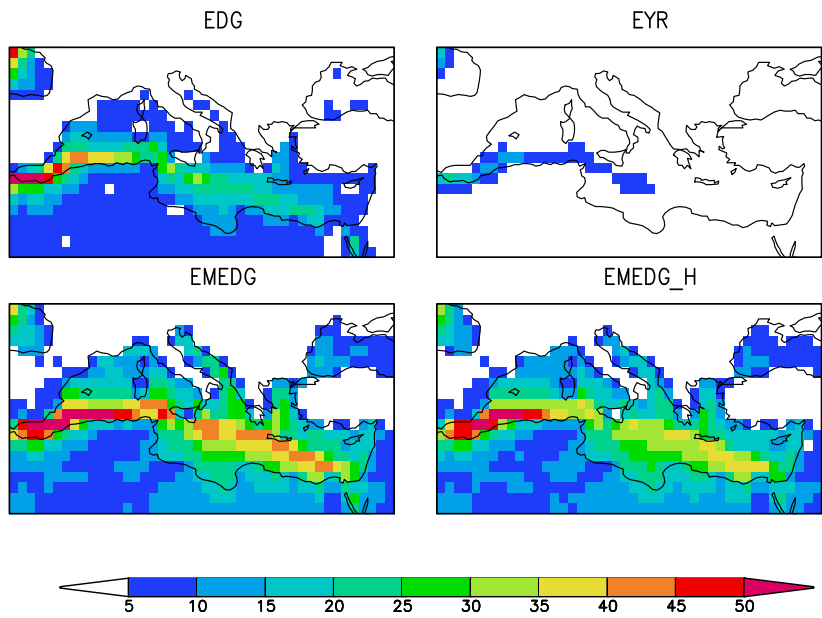

Fig. 3. Simulated contribution of ships to the surface black carbon, 2006 summer mean (June, July, August).

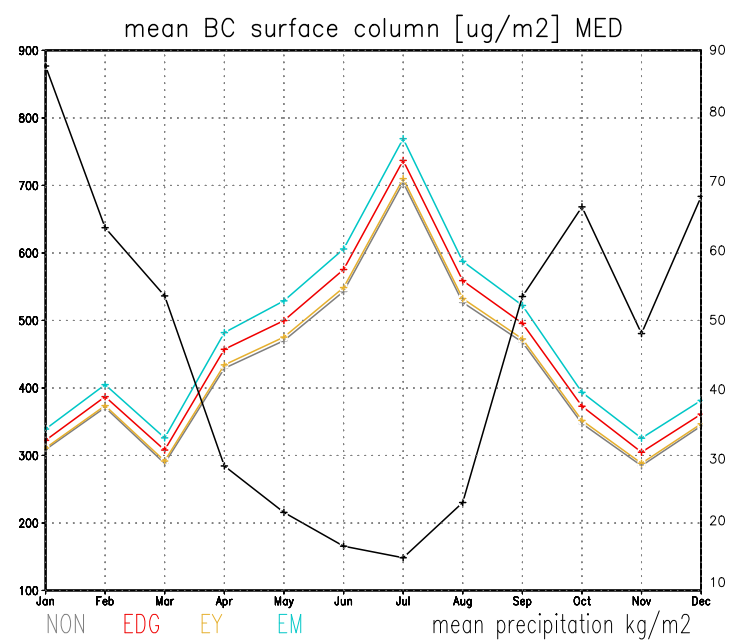

Fig. 4. Annual cycle of the simulated BC surface concentration over the Mediterranean and precipitation, 2006. BC concentration: NON in grey, EDG in red, EYR in yellow and EMEDG in blue. Precipitation in black.

the surface BC is underestimated by the model, while it is overestimated during summer (Fig. 5). Looking at the average value for all cruises, the EMEDG simulation provides the best agreement with observations. Considering the uncertainty of the optical method, estimated at $25 \%$ (see Sect. 4.1), all the inventories produce results within the uncertainty limits.

\subsection{Ozone}

Ship emissions contribute to a much lesser degree to the surface ozone as compared to BC. During the summer 2006, this

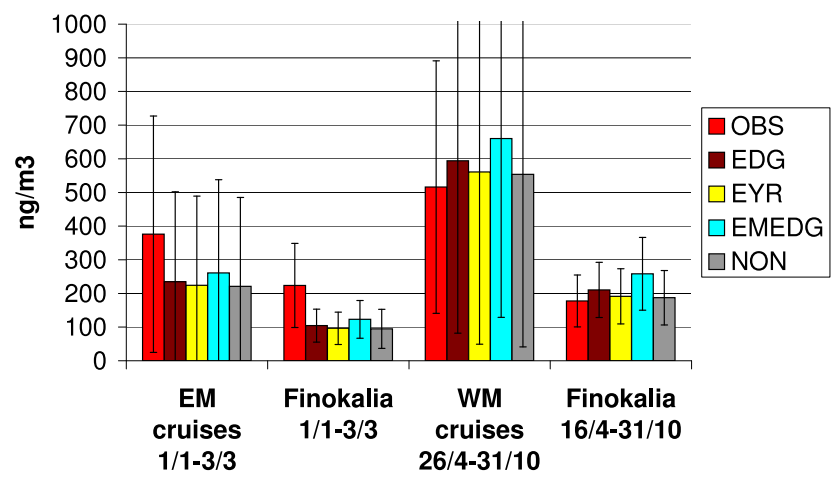

Fig. 5. On-board ship measurements and measurements at Finokalia $(35.3 \mathrm{~N}, 25.7 \mathrm{E})$ compared with model simulations for BC, mean surface concentration and standard deviation.

Table 4. Observed and simulated mean black carbon surface concentrations and standard deviation, averaged over the cruises. The best simulation is highlighted in boldface.

\begin{tabular}{lllll}
\hline $\begin{array}{l}\text { Mean and } \\
\text { st. dev. of } \\
\text { surface BC } \\
\text { ng m }^{-3}\end{array}$ & $\begin{array}{l}\text { EM } \\
\text { Jan-Mar 06 } \\
4 \text { cruises }\end{array}$ & $\begin{array}{l}\text { WM } \\
\text { Apr-Oct 06 } \\
26 \text { cruises }\end{array}$ & $\begin{array}{l}\text { Tunis-Palma } \\
\text { Apr-Oct 06 } \\
26 \text { cruises }\end{array}$ & $\begin{array}{l}\text { All cruises } \\
\text { Jan-Dec 06 } \\
34 \text { cruises }\end{array}$ \\
\hline observed & $376 \pm 351$ & $516 \pm 375$ & $320 \pm 205$ & $465 \pm 382$ \\
EDG & $235 \pm 267$ & $594 \pm 512$ & $269 \pm 154$ & $431 \pm 477$ \\
EYR & $224 \pm 265$ & $561 \pm 512$ & $224 \pm 141$ & $404 \pm 474$ \\
EMEDG & $\mathbf{2 6 1} \pm \mathbf{2 7 7}$ & $660 \pm 531$ & $\mathbf{3 3 0} \pm \mathbf{1 8 8}$ & $\mathbf{4 7 4} \pm \mathbf{5 0 3}$ \\
EMEDG_H & $255 \pm 270$ & $634 \pm 519$ & $310 \pm 172$ & $\mathbf{4 5 2} \pm \mathbf{4 9 0}$ \\
NON & $221 \pm 264$ & $\mathbf{5 5 4} \pm \mathbf{5 1 3}$ & $214 \pm 140$ & $398 \pm 473$ \\
\hline
\end{tabular}

contribution reached $2-4 \%$ over the Sea in EDG. The maximum contribution of $12 \%$ (EYR simulation) can be found in summer over the Strait of Gibraltar, which links the Mediterranean Sea to the North Atlantic Ocean (Fig. 6). The relation between the emissions of the precursor gases $\mathrm{NO}_{x}$ $\left(\mathrm{NO}_{2}+\mathrm{NO}\right)$ and NMVOCs, and surface ozone is highly non linear: Linearity can be found between the $\mathrm{NO}_{\mathrm{x}}$ emissions and the $\mathrm{NO}_{2}$ concentration levels (Fig. 7). The relation between the $\mathrm{NO}_{\mathrm{x}}$ emissions and the surface ozone is not that simple: initially, increase of $\mathrm{NO}_{\mathrm{x}}$ emissions results in an enhanced surface ozone concentration, in the EMEDG simulation, however, we find lower surface ozone as compared to EYR despite higher $\mathrm{NO}_{\mathrm{x}}$ emissions (Fig. 8). Our analysis shows that when the threshold value of $1.2 \mathrm{Tg}$ year $^{-1}$ $\mathrm{NO}_{\mathrm{x}}$ emissions is exceeded, the surface ozone goes down. In this analysis we need to consider the impact of hydrocarbons, which show a highly non-linear behavior. In the NON simulation, without any emissions over the Mediterranean, we find the highest mean NMVOC surface concentration of all simulations, $17.8 \mathrm{ppbv}(\mathrm{C})$. From NON to EMEDG-noVOC we have added ship emissions of all the components except 
TM5 contribution of ships to 03 surface concentration [\%], JJA 2006
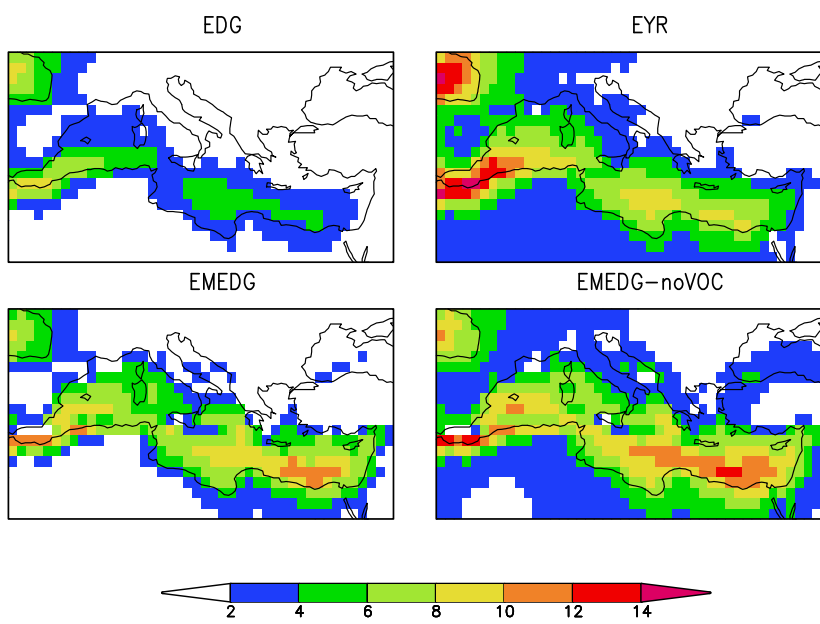

Fig. 6. Simulated contribution of ships to the ozone surface concentration, 2006 summer mean (June, July, August).

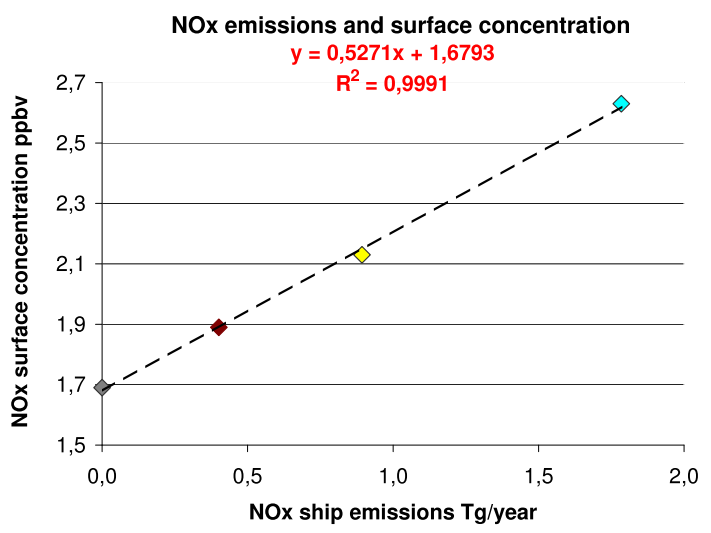

Fig. 7. $\mathrm{NO}_{\mathrm{x}}$ ship emissions and the mean modeled $2006 \mathrm{NO}_{\mathrm{x}}$ surface concentration over the Mediterranean Sea. Grey NON, yellow EYR, brown EDG, light blue EMEDG.

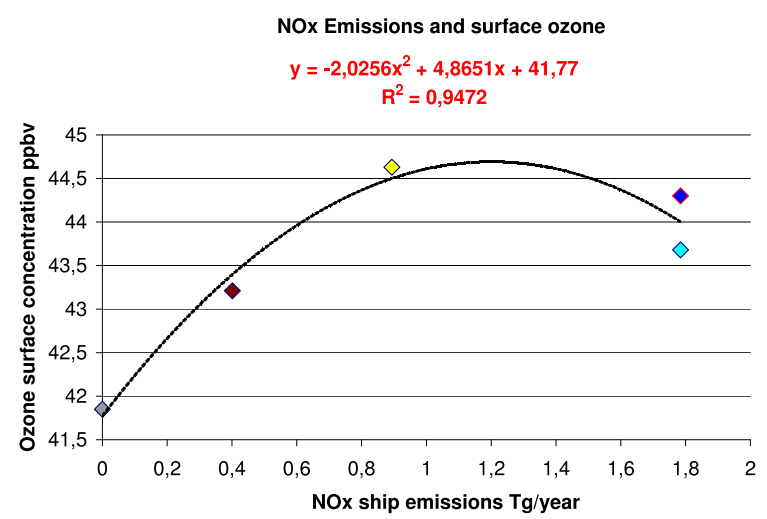

Fig. 8. $\mathrm{NO}_{\mathrm{x}}$ ship emissions and the mean modeled 2006 ozone surface concentration over the Mediterranean Sea. Grey NON, yellow EYR, brown EDG, light blue EMEDG, dark blue EMEDG_noVOC. of the NMVOCs, only to find the lowest mean NMVOC concentration of all simulations, 17.2 ppbv(C). Despite the fact that the VOC ship emissions are either zero (in NON and EMEDG-noVOC) or differ by over two orders of magnitude (between EDG and EYR), their effect on the surface concentration ranges only within $3 \%$. Our analysis of the very complicated photochemical patterns between $\mathrm{NO}_{\mathrm{x}}$, NMVOCs and ozone shows a relationship between the $\mathrm{NMVOC} / \mathrm{NO}_{\mathrm{x}}$ ratio and the ratio of ozone production rate to the ozone loss rate (Fig. 9). At low $\mathrm{NMVOC} / \mathrm{NO}_{\mathrm{x}}$ ratios the relation of ozone production to ozone loss remains low and it grows with the growing ratio. After reaching the maximum at a threshold ratio of $\mathrm{NMVOC} / \mathrm{NO}_{\mathrm{x}}=8$, it begins to decrease. Because of this very high sensitivity of ozone levels to the emissions of $\mathrm{NO}_{\mathrm{x}}$ and especially NMVOCs, the importance of obtaining more accurate amount of NMVOC ship emissions is essential in order to study and understand their possible impact on the ozone levels especially in such polluted areas as the Mediterranean Sea.

In terms of ozone measurements, the best agreement is achieved over the WM during the "summer" (April to October) cruises. The observed mean ozone of $48.9 \mathrm{ppbv}$ is best simulated in EMEDG, the EYR simulation gives slightly higher value and EDG slightly lower. Without ship emissions, the simulated mean ozone over the WM decreases by 2 ppbv (Table 5). Much higher mean value has been observed (42.7 ppbv) during the EM cruises (January-March) than the model predicts (maximal simulated value $38.2 \mathrm{ppbv}$ in EYR). Lelieveld et al. (2002) and Gerasoupoulos et al. (2005) identified transport from the European continent as the main mechanism that controls ozone levels in the Eastern Mediterranean. Therefore we can not simply translate this underestimation into the shortcomings of the local emissions. Inaccuracy in land based emissions of the ozone precursors, simulated vertical mixing and transport could be additional sources of uncertainty. Averaged over all cruises, Eyring inventory presents the bests results. Figure $10 \mathrm{a}$ and $\mathrm{b}$ shows the comparison with observations at three coastal sites (Fig. 1), averaged over the same time period as the Eastern (1 January-3 March 2006) and the Western (26 April-31 October) cruises. At the western Mediterranean site Cabo de Creus (ES10) (Fjaeraa and Hjellbrekke, 2008) and the eastern Mediterranean site Finokalia, the model performs better during summer than during winter. During summer, EYR simulation gives the best agreement for Cabo de Creus, in agreement with the results for the WM cruises. For Finokalia the summertime ozone is best simulated with EMEDG.

At the central Mediterranean site Giordan Lighthouse (MT01) (Fjaeraa and Hjellbrekke, 2008) the summertime surface ozone is overestimated by all simulations. During winter we find an underestimation by all simulations at all three sites. Seasonal variation of ship emissions, not included in our inventories, could possibly improve the model performance regarding surface ozone (see Sect. 6). 
NMVOC/NOx Concentration and Ozone Production/Loss

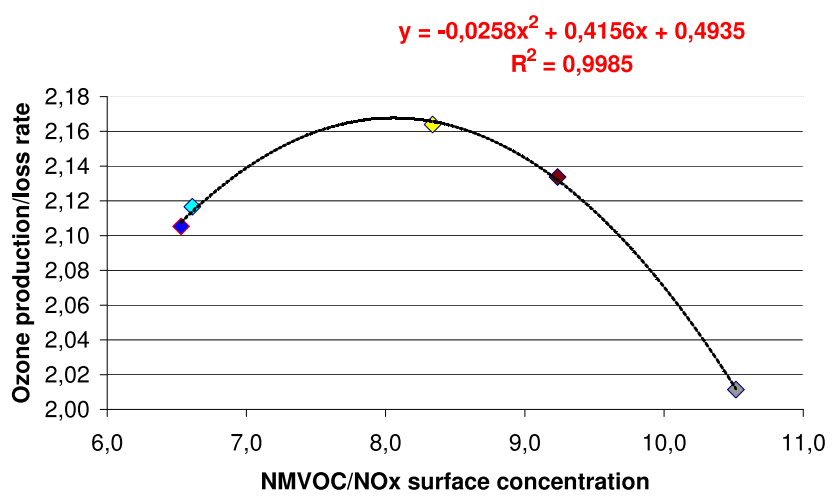

Fig. 9. The mean $\mathrm{NMVOC} / \mathrm{NO}_{\mathrm{x}}$ concentration ratio and mean Ozone Production/Loss rate ratio over the Mediterranean Sea, annual mean 2006. Grey NON, yellow EYR, brown EDG, light blue EMEDG, dark blue EMEDG_noVOC.

\section{$5.3 \mathrm{NO}_{2}$ column burden}

The advantage of satellite measurements for validation of ship emission inventories is their spatial coverage. As compared to the ship observations we have a good coverage of continuous measurements which enables us to compute mean values over reasonably long time period. What we can observe from the satellite is the total atmospheric burden rather than the surface concentration which might let us wonder whether such local surface sources as ships can leave a signal on these observations. Figure 11a shows the average $\mathrm{OMI} \mathrm{NO}_{2}$ tropospheric columns (gridded to $0.125^{\circ} \times 0.125^{\circ}$ ) over the Mediterranean Sea for June-August 2006. The most prominent feature here is the elevated $\mathrm{NO}_{2}$ (by $1.0 \times 10^{15}$ molecules $\mathrm{cm}^{-2}$ relative to background levels) along the main shipping route extending from the Street of Gibraltar to Egypt. In order to make the data comparable to the model results, we interpolate it from the original resolution of OMI (see Sect. 4.2) to the model resolution of $1^{\circ} \times 1^{\circ}$. This interpolation causes a smearing of the signal and it nearly disappears over the Eastern part of the Sea but can still be well recognized in the Western part (Fig. 11b). The total atmospheric $\mathrm{NO}_{2}$ burden over the Mediterranean Sea is overpredicted by the model, the NON simulation gives the best quantitative agreement with the satellite observations (Table 6). We compare the burden over the particular area of the main shipping routes in the Eastern and Western Mediterranean as can be seen from space (Fig. 12). While for the Eastern part EDG, the simulation with lowest $\mathrm{NO}_{\mathrm{x}}$ emissions, gives the best results for the summer mean $\mathrm{NO}_{2}$ burden, it is significantly higher over the Western Mediterranean, and is best reproduced by the EMEDG simulation. For the Western Mediterranean we find a good agreement with measurements for both, $\mathrm{NO}_{2}$ and ozone, and in both cases it is the EMEDG simulation that produces best matching results.
Table 5. Observed and simulated mean ozone surface concentration and standard deviation, averaged over the cruises. The best simulation is highlighted in boldface.

\begin{tabular}{llll}
\hline $\begin{array}{l}\text { Mean and st. dev. } \\
\text { of surface Ozone } \\
\text { ppbv }\end{array}$ & $\begin{array}{l}\text { EM } \\
\text { Jan-Mar 06 } \\
\text { 4 cruises }\end{array}$ & $\begin{array}{l}\text { WM } \\
\text { Apr-Oct 06 } \\
\text { 26 cruises }\end{array}$ & $\begin{array}{l}\text { All cruises } \\
\text { Jan-Dec 06 } \\
\text { 34 cruises }\end{array}$ \\
\hline observed & $42.7 \pm 6$ & $48.9 \pm 11$ & $44.7 \pm 11$ \\
EDG & $36.9 \pm 6$ & $48.1 \pm 12$ & $42.8 \pm 11$ \\
EYR & $\mathbf{3 8 . 2} \pm \mathbf{7}$ & $49.5 \pm 12$ & $\mathbf{4 4 . 2} \pm \mathbf{1 2}$ \\
EMEDG & $36.7 \pm 7$ & $\mathbf{4 8 . 9} \pm \mathbf{1 3}$ & $43.1 \pm 13$ \\
NON & $35.5 \pm 6$ & $46.7 \pm 11$ & $41.2 \pm 11$ \\
\hline
\end{tabular}
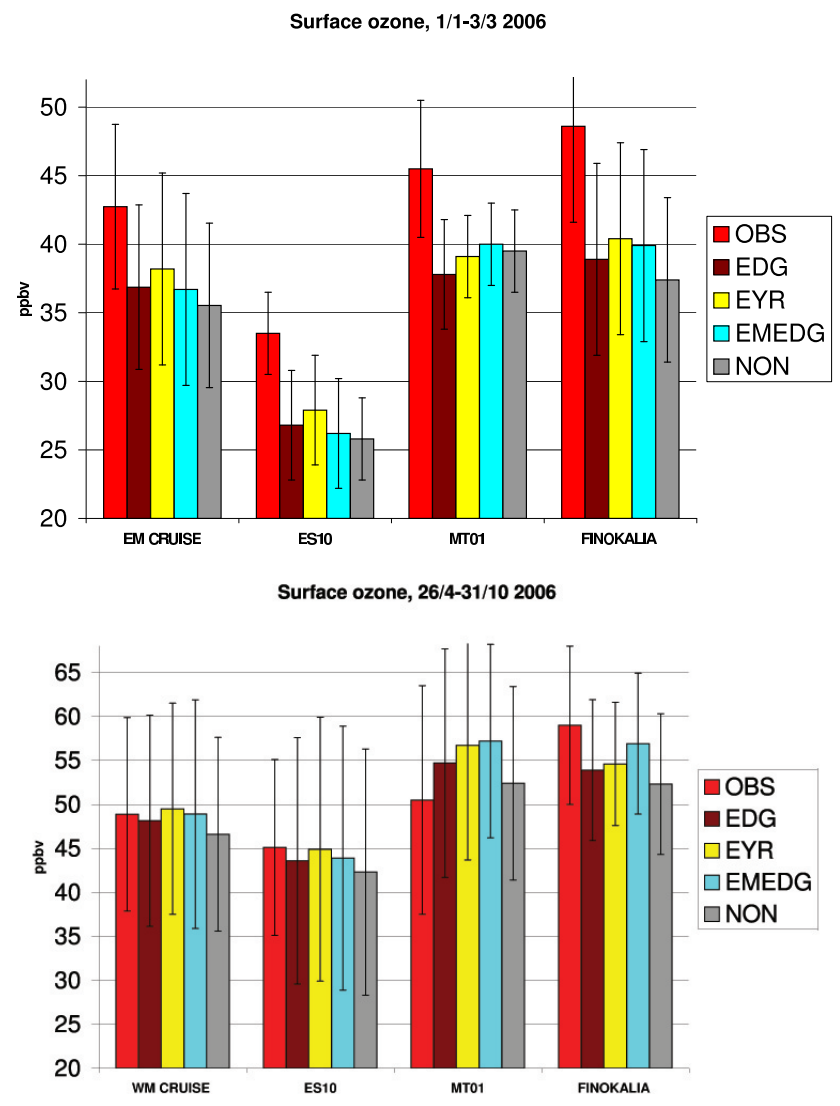

Fig. 10. On-board ship measurements and station measurements compared with model simulations for surface ozone, mean surface concentration and standard deviation; (a) 1 January-3 March 2006, EM cruises and (b) 26 April-31 October 2006, WM cruises. Stations: Cabo de Creus (ES10), Giordan Lighthouse (MT01) and Finokalia (cruises and site coordinates see Fig. 1). 


\section{a. OMI resolution}

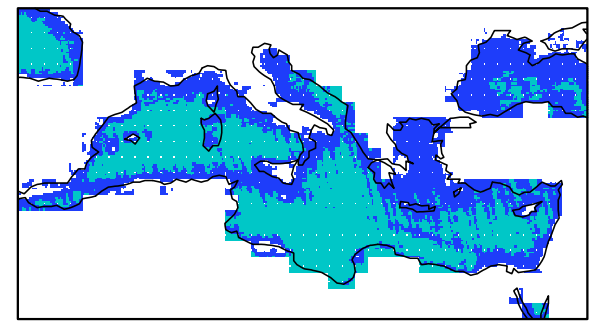

b. $1 \times 1$ Degree interpolated

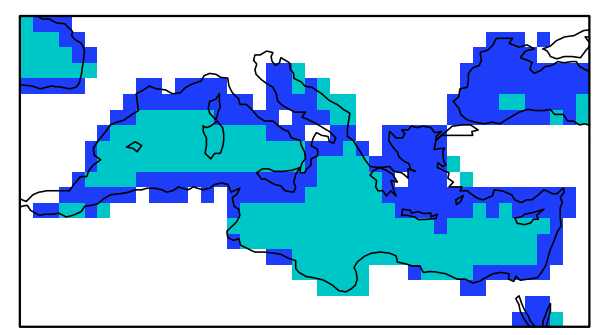

Fig. 11. $\mathrm{NO}_{2}$ columns over the Mediterranean, sea grid-boxes only, seasonal mean, JJA 2006: (a) as retrieved from the OMI satellite, original resolution, (b) satellite data interpolated on the model grid $1 \times 1$ degrees.

$\mathrm{NO}_{2}$ column burden, summer 2006

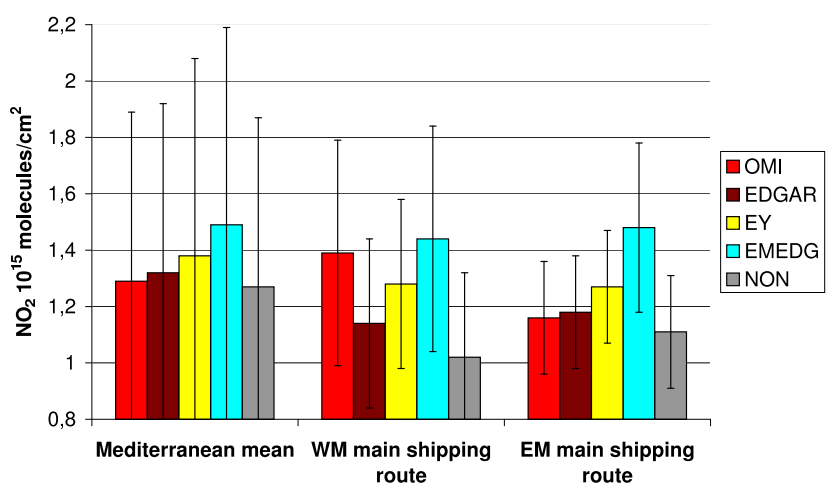

Fig. 12. $\mathrm{NO}_{2}$ columns averaged over the Mediterranean, the Western and Eastern shipping routes as seen by satellite, seasonal mean and standard deviation, JJA, 2006.

\section{Conclusions and discussion}

All ship emission inventories analyzed here give different estimates for all compounds; these disagreements mainly result from different methodologies, activity data and emission factors. The emission factors present the highest source of uncertainty for black carbon, which vary by a factor of 5 , and even more for NMVOCs which vary by two orders of magnitude. Emission factors for $\mathrm{NO}_{\mathrm{x}}$ and $\mathrm{SO}_{2}$ agree much better among the inventories representing significant convergence among independent studies during the past decades. Further-
Table 6. Mean $\mathrm{NO}_{2}$ atmospheric column and standard deviation, summer 2006 as observed from the OMI satellite and simulated by TM5 over the shipping route in the WM $(0-13 \mathrm{E}, 36-37 \mathrm{~N})$ and the EM (15-33 E, 31-36 N) and the mean over the whole Mediterranean Sea.

\begin{tabular}{llll}
\hline $\begin{array}{l}\text { Mean } \mathrm{NO}_{2} \text { column } \\
10^{15} \text { molecules cm }^{-2}\end{array}$ & $\begin{array}{l}\text { WM } \\
\text { shipping } \\
\text { route }\end{array}$ & $\begin{array}{l}\text { EM } \\
\text { shipping } \\
\text { route }\end{array}$ & $\begin{array}{l}\text { Mediterra- } \\
\text { nean } \\
\text { Sea }\end{array}$ \\
\hline OMI & $1.39 \pm 0.4$ & $1.16 \pm 0.2$ & $1.29 \pm 0.6$ \\
EDG & $1.14 \pm 0.3$ & $\mathbf{1 . 1 8} \pm \mathbf{0 . 2}$ & $1.32 \pm 0.6$ \\
EYR & $1.28 \pm 0.3$ & $1.27 \pm 0.2$ & $1.38 \pm 0.7$ \\
EMEDG & $\mathbf{1 . 4 4} \pm \mathbf{0 . 4}$ & $1.48 \pm 0.3$ & $1.49 \pm 0.7$ \\
NON & $1.02 \pm 0.3$ & $1.11 \pm 0.2$ & $\mathbf{1 . 2 7} \pm \mathbf{0 . 6}$ \\
\hline
\end{tabular}

more, the global inventories apply international bunker statistics, in which the fuel consumed for the domestic shipping is not included. The national fuel statistics have been taken into account in the new EDGARv4 inventory, but the spatial information for the domestic shipping has not yet been provided. Comparing the emission totals we find that at least $20 \%$ of the emissions in the Mediterranean account for the domestic traffic. All regional inventories are based on individual ship movements, providing a better fleet coverage, but this information is not available on a global scale, thus this method can not be applied globally. Seasonal variability of ship traffic has not been included in any of the inventories; all emissions are assumed temporally constant which presents an additional uncertainty.

So what did we learn from the measurements about the ship emission inventories? Our findings show that ship emissions have a significant impact on air pollution over the Mediterranean region. The evidence for this impact is the ship signal which is recognizable from the satellite $\mathrm{NO}_{2}$ retrievals especially over the Western Mediterranean. Over the Eastern Mediterranean, we find a spatially narrow signal in the satellite $\mathrm{NO}_{2}$ retrievals which is not reproducible by the $1^{\circ} \times 1^{\circ}$ model resolution applied in this study. With EDGARv4, we now have a much finer resolved emission inventory which should be applied in a model with a corresponding $0.1^{\circ} \times 0.1^{\circ}$ resolution in future.

Combined uncertainties in the spatial and temporal variation of ship activity, land based emissions, modeled transport and sinks of air pollutants (e.g. wet deposition of BC) determine the variation in agreement among the observations and the model. To illustrate this we present our results in four categories - Western Mediterranean summer, Western Mediterranean winter, Eastern Mediterranean summer and Eastern Mediterranean winter. We compare $\mathrm{NO}_{2}$ satellite retrievals for Eastern and Western Mediterranean summer (June, July and August). The ship measurements of ozone and black carbon are available for the Western Mediterranean summer (April to October) and the Eastern Mediterranean winter (January-March). We have further analyzed all year ozone 
measurements from three observational sites in the Western (Cabo de Creus), Central (Giordan Lighthouse) and Eastern (Finokalia) part, and all year black carbon measurements from an observational site in the Eastern Mediterranean (Finokalia).

For all pollutants, we find the best agreement between the model and the observations in the WM during the dry summer. For $\mathrm{NO}_{2}$, EMEP, emission inventory with highest $\mathrm{NO}_{\mathrm{x}}$ emissions, produces best results in the Western Mediterranean which is corroborated by the good agreement of EMEDG (the corresponding simulation) ozone with measurements during Western cruises. For the western observational site Cabo de Cruise it is the EYR simulation (Eyring inventory) which agrees best with the observed ozone. Simulated ozone concentrations for EMEP and Eyring emission inventories are very similar. While 1.8 times more $\mathrm{NO}_{\mathrm{x}}$ is released in EMEP than in Eyring in the Western part, 2.6 more NMVOCs are released in Eyring than in EMEP. Due to complicated non linear photochemistry and the sensitive relationship of $\mathrm{NO}_{\mathrm{x}}$, NMVOCs and ozone, we are unable to give preference to one of these inventories based on ozone and $\mathrm{NO}_{2}$ measurements only. Ship stack measurements of NMVOCs can greatly contribute to better determine the emission factor for this group of compounds leading to an improvement of NMVOC ship emission estimates. Furthermore we recommend measuring NMVOC on-board the cruise ship along with ozone and $\mathrm{NO}_{\mathrm{x}}$ (the $\mathrm{NO}_{\mathrm{x}}$ analyzer has been installed on board in 2008). Better knowledge of the NMVOC emissions and ambient concentrations over the sea can improve our knowledge on the impact of ship emissions on surface ozone. Black carbon is slightly overestimated during the Western cruises, as well as at the eastern site Finokalia during the dry season. Even without ship emissions, the simulated BC concentration exceeds the observed one on average. For the Tunis-Palma leg, which is largely dominated by local ship emissions there is a very good agreement with simulated BC, also here the best results are achieved with EMEP.

The emissions in the Eastern Mediterranean are not constrained with the measurements used in this study. During the EM summer, very low $\mathrm{NO}_{2}$ has been observed as compared to the simulations. The EDG inventory with lowest $\mathrm{NO}_{\mathrm{x}}$ ship emissions shows the best agreement. Surface ozone is underestimated during the EM cruises. It is also underestimated for all sites (eastern and western) during winter. There are two possible explanations for the underestimation of $\mathrm{BC}$ during the cold wet season in the Eastern part - either the model deposits too much $\mathrm{BC}$ by the wet deposition, or it could be attributed to missing emission sources - marine or land during winter. The overestimation during summer and the underestimation during winter could also be caused by an incorrect temporal variability of $\mathrm{BC}$ from biomass burning, which is an important source in the Mediterranean region (e.g. Palumbo et al., 2006) with a temporally irregular occurrence.
All ship emission inventories analyzed in this work are assumed to be temporally constant. In this study, summertime simulations of all compounds have shown better agreement with measurements as compared to winter. Different seasonal patterns are given by global ship activity data sets ICOADS and AMVER and need more investigation (Dalsøren et al., 2008). Including the temporal variability in ship emission inventories could possibly improve the simulations of ozone and $\mathrm{BC}$ during winter. We decided not to perform further sensitivity studies on this item due to the expected low signal and in order not to expand the length of the manuscript.

Considering the uncertainties in the measurements and the model, we can say that all ship emission estimates lay within the uncertainty range. While more stack measurements and detailed fleet statistics can further improve our knowledge on ship emissions, the difficulty to construct an accurate emission estimate will remain a challenge for this highly uncertain emission source. Given the expected growth of ship traffic and the expansion of waterways and ports, scenario calculations are needed to determine the impact of emission reduction policies on air quality and climate. For these calculations, the whole range of existing inventories needs to be considered in order to determine the propagation of these uncertainties in the future scenarios.

\section{Appendix A}

\section{Ship emission inventories - methodologies and emission factors}

Global and European regional inventories are calculated based on different methodologies.

Global emission inventories are calculated applying the top-down approach. Top-down approach is defined as breaking down a system to gain insight into its compositional subsystems. In our context it means that the emissions are calculated based on the total fuel consumption. Geo-spatial information is not included here. The total fuel consumption is either based on energy statistics data (classical top-down, EDGAR FT, Diagram A1) or estimated from the fleet activity (activity based top-down, Eyring, Diagram A3). The new EDGARv4 inventory (Diagram A2) applies a technology split accounting for different ship types and sea and port activities. The calculated global ship emissions total is allocated to each grid cell proportional to the value of each grid represented by spatial proxies of the ship activity patterns from the AMVER (Automated Mutual-Assistance Vessel Rescue System) data set (Endresen et al., 2003) or on the combined AMVER/ICOADS (International Comprehensive Ocean-Atmosphere Data Set) data (Wang et al., 2008). In regional inventories, the bottom-up approach is applied (Diagram A4)." 
Diagram A1. EDGAR FT-Approach.

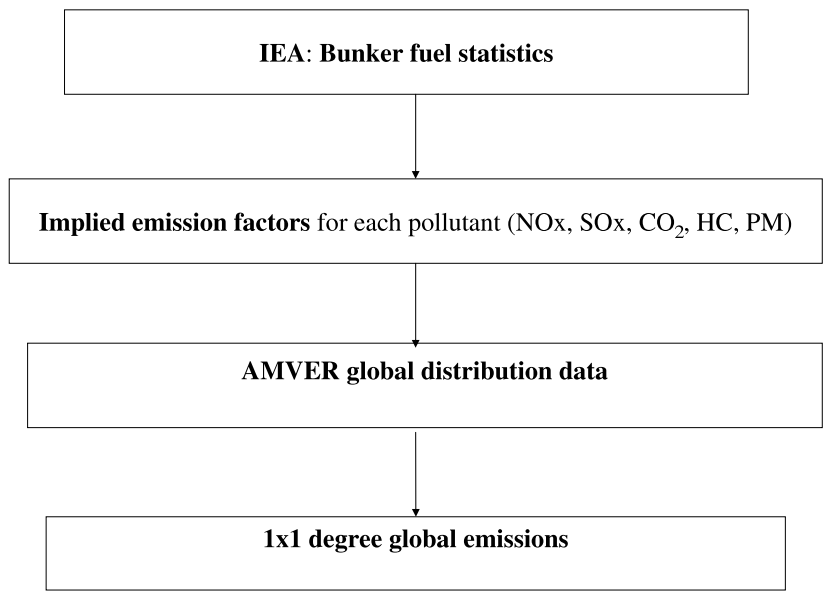

Diagram A2. EDGARv4-Approach.

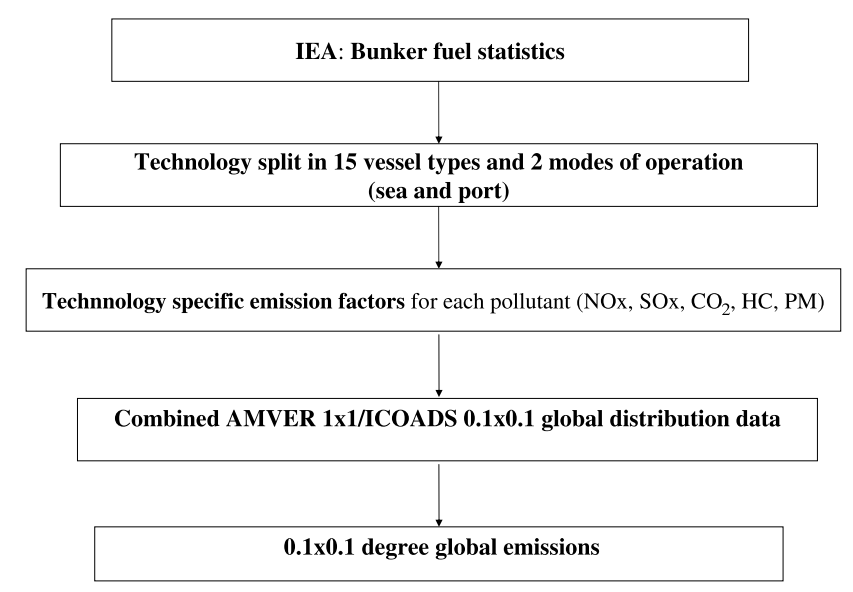

In regional inventories, the bottom-up approach is applied (Diagram A4). In a bottom-up approach the individual base elements of the system are first specified in great detail. These elements are then linked together to form the main system. Thus, the emissions are calculated based on information from individual vessels and its movements.

\section{A1 Methods}

\section{A1.1 Top-down (Table A1a)}

Based on fuel consumption.

(a) Bunker fuel statistics provided by the International Energy Agency (IEA), spatial distribution based on AMVER Ship Reporting System Data (Endresen et al., 2003).

(b) Bunker fuel statistics provided by IEA and national fuel statistics to account for the domestic ship traffic, spa-
Diagram A3. EYRING-ApproachEYRING-Approach (Eyring et al., 2005).

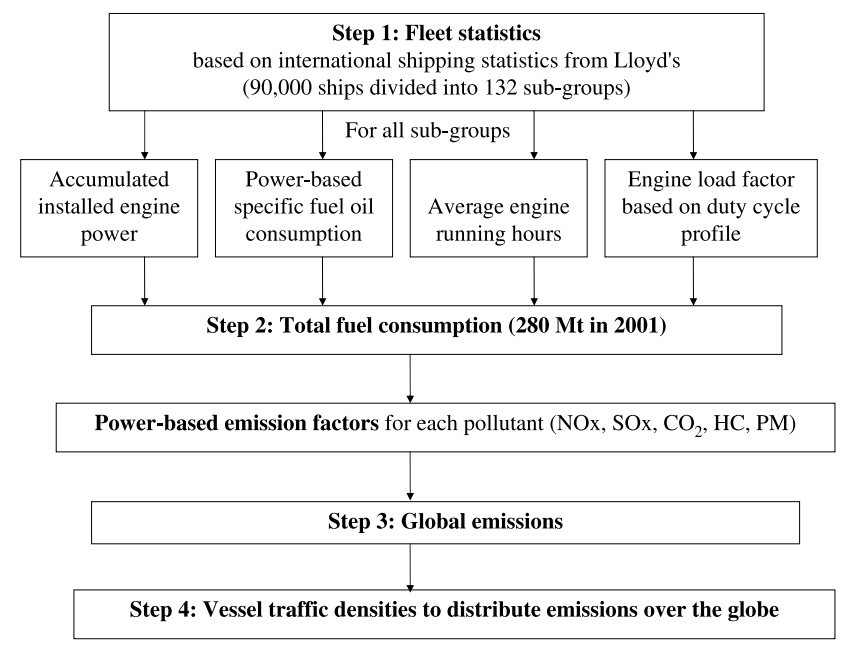

Diagram A4. ENTEC-Approach (Whall and Stavrakaki, 2008).

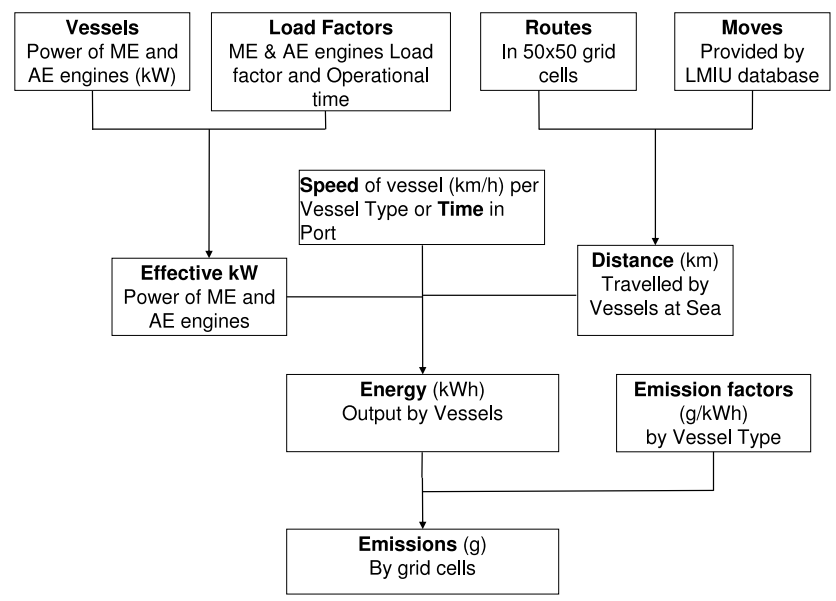

tial distribution based on combined AMVER/ICOADS activity data (Wang et al., 2008).

(c) Activity based - total fuel consumption based on fleet activity data, spatial distribution based on AMVER Ship Reporting System Data (Endresen et al., 2003).

\section{A1.2 Bottom-up (Table A1b)}

Emissions calculated by engine type/engine speed/fuel type and vessel movements, for vessels $>500 \mathrm{GT}$, data on vessel characteristics provided by Lloyd's Register Fairplay (LRF, 2004) . Top-down approach for smaller vessels and fishing vessels.

(a) Provided by Lloyd's Marine Intelligence Unit (LMIU, 2004) for four discrete months in 2000 to reflect 
Table A1a. Global ship emission inventories.

\begin{tabular}{lccc}
\hline GLOBAL & EDGAR FT & EDGARv4 & EYRING \\
\hline $\begin{array}{l}\text { Base year } \\
\text { Method }\end{array}$ & A1.1a Diagram A1 & A1.1b Diagram A2 & A1.1c Diagram A3 \\
Fleet coverage & international shipping & $\begin{array}{c}\text { domestic and } \\
\text { international shipping } \\
\text { cargo and passenger }\end{array}$ & cargo and passenger $>100 \mathrm{GT}$ \\
& cargo and passenger $>100 \mathrm{GT}$ & global & global \\
Domain and & global & $0.1^{\circ} \times 0.1^{\circ}$ & $1^{\circ} \times 1^{\circ}$ \\
resolution & $1^{\circ} \times 1^{\circ}$ & NMVOC emissions & NMVOC emissions \\
Additional & NMVOC emissions & from fuel only & from fuel $(51 \%)$ \\
comments & from fuel only & & and loading $(49 \%)$ \\
& & &
\end{tabular}

Table A1b. Regional ship emission inventories.

\begin{tabular}{lcccc}
\hline EUROPEAN & ENTEC & EMEP & IIASA & CONCAWE \\
\hline $\begin{array}{l}\text { Base year } \\
\text { Method }\end{array}$ & $\begin{array}{c}2000 \\
\text { Fleet coverage } \\
\text { Al.2a Diagram A4 } \\
\text { domestic and } \\
\text { international } \\
>500 \mathrm{GT}\end{array}$ & $\begin{array}{c}\text { A1.2b Diagram A4 } \\
\text { domestic and } \\
\text { international } \\
>500 \mathrm{GT}\end{array}$ & $\begin{array}{c}\text { A1.2c Diagram A4 } \\
\text { domestic and } \\
\text { international } \\
>100 \mathrm{GT}\end{array}$ & $\begin{array}{c}\text { A1.2d Diagram A4 } \\
\text { domestic and } \\
\text { international } \\
\text { n.s. }\end{array}$ \\
$\begin{array}{l}\text { Domain } \\
\text { and resolution }\end{array}$ & $\mathrm{A} 2$ & $\mathrm{~A} 2$ & $\mathrm{~A} 2$ & $\begin{array}{c}\text { Mediterranean Sea } \\
50 \times 50 \mathrm{~km}^{2}, \\
10 \times 10 \mathrm{~km}^{2}\end{array}$ \\
$\begin{array}{l}\text { Additional } \\
\text { comments }\end{array}$ & $\begin{array}{c}\text { NMVOC emissions } \\
\text { from fuel only }\end{array}$ & $\begin{array}{c}\text { NMVOC emissions } \\
\text { from fuel only }\end{array}$ & $\begin{array}{c}\text { NMVOC emissions } \\
\text { from fuel only }\end{array}$ & $\begin{array}{c}\text { NMVOC emissions } \\
\text { from fuel only }\end{array}$ \\
\hline
\end{tabular}

seasonal variations in shipping activity, the results multiplied by 3 . In-port times derived from a questionnaire survey of ports. Separate analysis for ferries and fishing vessels.

(b) Based on (a), assuming a growth factor of $2.5 \%$ per year (Endresen et al., 2003).

(c) Same as (a), using additional literature data on port surveys, resulting in an increase of $20 \%$ in average port times as compared to (a). Top-down approach for smaller (100-500 GT) vessels, assuming additional $10 \%$ of emissions in the coastal 12-mile zones. More detailed spatial resolution of emissions, distinguishing national, international, by flag state and within 12-mile zones.

(d) Same as (a), but up-dated for 2005, manual addition of approx. 100000 passenger vessel movements using time tables. Different methodology for determining the relative percentages of RO (residual oil) and MD (marine diesel) in total fuel consumed.
Table A2. Implied emission factors for the Mediterranean Sea.

\begin{tabular}{lccllll}
\hline $\mathrm{g} / \mathrm{kWh}$ & $\mathrm{NO}_{\mathrm{x}}$ & $\mathrm{SO}_{2}$ & NMVOC & $\mathrm{BC}$ & $\mathrm{OC}$ & $\mathrm{PM}_{2.5}$ \\
\hline EDGAR FT & 15.3 & $13.5^{\mathrm{a}} / 4.5^{\mathrm{b}}$ & 0.027 & 0.225 & 0.072 & \\
EDGARv4 & 14.1 & 8.0 & 0.48 & 0.04 & 0.1 & \\
EYRING & 16.5 & 9.1 & 2.5 & 0.04 & 0.1 & \\
ENTEC & 9.25 & 9.46 & 0.29 & n.s. & n.s. & n.s. \\
EMEP & 9.25 & 9.46 & 0.29 & n.s. & n.s. & n.s. \\
IIASA & 9.25 & 9.46 & 0.29 & n.s. & n.s. & n.s. \\
CONCAWE & 8.93 & 7.56 & 0.27 & & & 0.50 \\
\hline
\end{tabular}

${ }^{\mathrm{a}}$ residual; ${ }^{\mathrm{b}}$ diesel.

\section{A2 EMEP domain and resolution (Table A1b)}

Approx. $40 \mathrm{~W}-60 \mathrm{E}$ lat, $30 \mathrm{~N}-90 \mathrm{~N}$ lon, North-East Atlantic, North, Baltic, Black and Mediterranean Seas, $0.5^{\circ} \times 0.5^{\circ}$.

\section{Domestic navigation in EDGARv4}

Some of the fuel being used at open sea is related to inland transportation for example from one harbor to another harbor in the same country. This fuel is excluded from the IEA statistics on international bunker fuel but included in national bunker statistics. Globally, the variety of ship types in domestic navigation is large and is dependent on the geography 
Table B1. Natural emissions.

\begin{tabular}{|c|c|c|}
\hline $\begin{array}{l}\text { NATURAL } \\
\text { EMISSIONS }\end{array}$ & $\begin{array}{c}\text { ANNUAL } \\
\text { GLOBAL } \\
\text { Tg/yr }\end{array}$ & REFERENCE \\
\hline DUST & $1.68 \mathrm{e}+003$ & Ginoux et al. (2001, 2004) \\
\hline SEA SALT & 4756.87 & $\begin{array}{l}\text { ON-LINE } \\
\text { Vignati et al. (2009), } \\
\text { dev. from Gong et al. (2003) } \\
\text { in } 2 \text { modes }\end{array}$ \\
\hline DMS & $10.0887 \mathrm{Tg}(\mathrm{S}) / \mathrm{yr}$ & calculated on-line \\
\hline $\begin{array}{l}\text { VOLCANIC } \mathrm{SO}_{2} \\
\text { degassing by } \\
\text { continuous volcanoes }\end{array}$ & 25.0 & $\begin{array}{l}\text { GEIA } \\
\text { (Andres and Kasgnoc, 1998), } \\
\text { Volcano height based on } \\
\text { Halmer et al. (2002) }\end{array}$ \\
\hline $\begin{array}{l}\text { degassing by } \\
\text { explosive volcanoes }\end{array}$ & 4.0 & $\begin{array}{l}\text { GEIA } \\
\text { (Halmer and Schmincke, 2000) }\end{array}$ \\
\hline $\begin{array}{l}\text { NATURAL NH}_{3} \\
\text { OCEANIC NH} \\
\text { AGRIC. } \mathrm{NH}_{3}\end{array}$ & $\begin{array}{c}2.43 \\
8.1536 \\
52.6\end{array}$ & $\begin{array}{l}\text { Bouwman et al. (1997) } \\
\text { Bouwman et al. (1997) } \\
\text { Strengers et al. (2004) }\end{array}$ \\
\hline $\begin{array}{l}\text { NAT. A. AGRIC. } \\
\text { SOIL } \mathrm{NO}_{\mathrm{x}}\end{array}$ & $5.8 \mathrm{Tg}(\mathrm{N}) / \mathrm{yr}$ & Yienger and Levi (1995) \\
\hline SOA & $19.1 \mathrm{Tg}(\mathrm{OM}) / \mathrm{yr}$ & $\begin{array}{l}\text { Guenther et al. (1995), } \\
\text { conversion factor } 0.15\end{array}$ \\
\hline
\end{tabular}

of countries. For most countries no detailed split between vessel types and amount of fuel consumed is available. As first estimate until better statistics become available all domestic fuel consumption has been assigned to freight traffic with emission factors according to Dalsøren et al. (2008). Furthermore, in the region of interest, we do not know to what extend the fuel has been consumed in the Mediterranean Sea rather than for inland shipping (lakes and rivers), and for some of the countries, in other adjacent seas. Therefore we give a range from $50 \%$ to $90 \%$ assigned to the Mediterranean Sea, resulting in a contribution of the domestic ship traffic to the emission totals of $17 \%$ to $27 \%$, respectively (Table 1).

\section{Appendix B}

\section{Other emissions}

Only ship emissions have been varied for the different model simulations. All other emissions have been kept the same for all simulations (Tables B1-B3).

Acknowledgements. This study was partially supported by the EU project MAP (Marine Aerosol Production). We thank Veronika Eyring and Vigdis Vestreng for providing information on their emission inventories. Special thanks to Arjo Segers for providing great programming support. The work has also been inspired by participation in the Harbours, Air Quality and Climate Change conference in Rotterdam 2008.
Table B2. Anthropogenic emissions.

\begin{tabular}{|c|c|c|}
\hline $\begin{array}{l}\text { ANTHROPOGENIC } \\
\text { EMISSIONS }\end{array}$ & $\begin{array}{r}\text { ANNUAL } \\
\text { GLOBAL } \\
\mathrm{Tg} / \mathrm{yr} \\
\end{array}$ & REFERENCE \\
\hline \multicolumn{3}{|l|}{ INDUSTRIAL } \\
\hline $\begin{array}{l}\mathrm{CO} \\
\mathrm{NMVOC} \\
\mathrm{NO}_{\mathrm{x}} \\
\mathrm{SO}_{2} \\
\mathrm{BC} \\
\mathrm{POM}\end{array}$ & $\begin{array}{r}37.6 \\
39.3 \\
33.7 \\
87.6 \\
3.3 \\
3.1\end{array}$ & Dentener et al. (2006) \\
\hline $\mathrm{NH}_{3}$ & 0.5 & Strengers et al. (2004) \\
\hline \multicolumn{3}{|l|}{ DOMESTIC } \\
\hline $\begin{array}{l}\mathrm{CO} \\
\mathrm{NMVOC} \\
\mathrm{NO}_{\mathrm{x}} \\
\mathrm{SO}_{2} \\
\mathrm{BC} \\
\mathrm{POM}\end{array}$ & $\begin{array}{r}238.4 \\
28.8 \\
4.9 \\
9.5 \\
3.34 \\
13.6\end{array}$ & Dentener et al. (2006) \\
\hline $\mathrm{NH}_{3}$ & 5.8 & Strengers et al. (2004) \\
\hline \multicolumn{3}{|l|}{ TRANSPORT } \\
\hline $\begin{array}{l}\text { CO ROAD } \\
\text { CO OFF-RD } \\
\text { NMVOC ROAD } \\
\text { NMVOC OFF-RD } \\
\mathrm{NO}_{\mathrm{x}} \text { ROAD } \\
\mathrm{NO}_{\mathrm{x}} \text { OFF-RD } \\
\mathrm{SO}_{2} \text { ROAD } \\
\mathrm{SO}_{2} \text { OFF-RD }\end{array}$ & $\begin{array}{r}185.9 \\
12.8 \\
33.7 \\
4.6 \\
28.4 \\
5.9 \\
3.7 \\
1.96\end{array}$ & $\begin{array}{l}\text { EDGAR FT } 2000 \\
\text { Olivier et al. (2005) }\end{array}$ \\
\hline $\begin{array}{l}\text { BC ROAD } \\
\text { BC OFF-RD } \\
\text { POM ROAD } \\
\text { POM OFF-RD }\end{array}$ & $\begin{array}{l}0.7 \\
0.5 \\
0.9 \\
0.5\end{array}$ & Dentener et al. (2006) \\
\hline
\end{tabular}

Table B3. Biomass burning emissions.

\begin{tabular}{lrl}
\hline BIOMASS & $\begin{array}{r}\text { ANNUAL } \\
\text { BURNING }\end{array}$ & REFERENCE \\
& Tg/yr & \\
\hline $\mathrm{CO}$ & 507.5 & Global Fire \\
$\mathrm{NMVOC}$ & 31.3 & Emissions Database \\
$\mathrm{NO}_{\mathrm{x}}$ & 2.3 & (van der Werf et al., 2004) \\
$\mathrm{SO}_{2}$ & 2.8 & \\
$\mathrm{NH}_{3}$ & 6.0 & \\
$\mathrm{BC}$ & 3.5 & \\
$\mathrm{POM}$ & 37.2 & \\
\hline
\end{tabular}

Edited by: R. von Glasow 


\section{References}

ARB (Air Resources Board): Emission Reduction Plan from Ports and Goods Movement, California Environmental Protection Agency, Los Angeles, USA, 21 June 2006.

Andersson-Skøld, Y. and Simpson, D.: Secondary organic aerosol formation in Northern Europe: a model study, J. Geophys. Res., 106, 7357-7374, 2001.

Andres, R. and Kasgnoc, A.: A time-averaged inventory of aerial volcanic sulfur emissions, J. Geophys. Res., 103, 25251-25261, 1998.

Beirle, S., Platt, U., von Glasow, R., Wenig, M., and Wagner, T.: Estimate of nitrogen oxide emissions from shipping by satellite remote sensing, Geophys. Res. Lett., 31, L18102, doi:10.1029/2004GL020312, 2004.

Bergamaschi, P., Meirink, J. F., Müller, J. F., Körner, S., Heimann, M., Bousquet, P.,. Dlugokencky, E.J, Kaminski, U., Vecchi, R., Marcazzan, G., Meinhardt, F., Ramonet, M., Sartorius, H., and Zahorowski, W.: Model Inter-comparison on Transport and Chemistry - report on model inter-comparison performed within European Commission FP5 project EVERGREEN Report EUR 22241 EN, 53, 4-48, 2006.

Boersma, K. F., Eskes, H. J., and Brinksma, E. J.: Error analysis for tropospheric $\mathrm{NO}_{2}$ retrieval from space, J. Geophys. Res., 109, D04311, doi:10.1029/2003JD003962, 2004.

Boersma, K. F., Eskes, H. J., Veefkind, J. P., Brinksma, E. J., van der A, R. J., Sneep, M., van den Oord, G. H. J., Levelt, P. F., Stammes, P., Gleason, J. F., and Bucsela, E. J.: Near-real time retrieval of tropospheric $\mathrm{NO}_{2}$ from OMI, Atmos. Chem. Phys., 7, 2103-2118, 2007, http://www.atmos-chem-phys.net/7/2103/2007/.

Bond, T., Streets, D., Yarber, K., Nelson, S., Woo, J., and Klimont, Z.: A technology-based global inventory of black and organic carbon emissions from combustion, J. Geophys. Res., 109, D14203, doi:10.1029/2003JD003697, 2004.

Bouwman, A. F., Lee, D. S., Asman, W. A. H., Dentener, F. J., van der Hoek, K. W., and Olivier, J. G. J.: A global high-resolution emission inventory for ammonia, Global Biogeochem. Cy., 11, 561-578, 1997.

Cabaldo, K., Corbett, J. J., Kasibhatla, P., Fischbeck, P., and Pandis, S. N.: Effects of ship emissions on sulfur cycling and radiative climate forcing over the ocean, Nature, 400, 743-746, 1999.

Cavalli, F., Vignati, E., Velchev, K., Hjorth, J., Dell'Acqua, A., Schembari, C., and Marmer, E.: Black carbon over the Mediterranean Sea - results from two year for shipborne measurments, in preparation, 2009.

Clean Air For Europe: Impact Assessment, online available at: http://ec.europa.eu/environment/air/cafe/pdf/ia_report_ en050921_final.pdf, p. 31, last access: February 2009, 2005.

Cofala, J., Amann, M., Hezes, C., Wagner, F., Klimont, Z., Posch, M., Schöpp, W., Tarasson, L., Eiof Jonson, J., Whall, C., and Stavrakaki, A.: Analysis of Policy Measures to Reduce Ship Emissions in the Context of the Revision of the National Emissions Ceilings Directiv, Final Report, Submitted to the European Commission, DG Environment, Unit ENV/C1, Contract No. 070501/2005/419589/MAR/C1, IIASA Contract No. 06107, 2007.

Concawe: Ship Emissions Inventory-Mediterranean Sea, Final Report, Entec UK Limited, 47 pp., April 2007.

Corbett, J. J., Winebrake, J. J., Green, E. H., Kasibhatla, P.,
Eyring, V., and Lauer, A.: Mortality from Ship Emissions: A Global Assessment, Environ. Sci., Technol., 41(24), 8512-8518, doi:10.1021/es071686z, 2007a.

Dalsøren, S. B., Eide, M. S., Endresen, Ø., Mjelde, A., Gravir, G., and Isaksen, I. S. A.: Update on emissions and environmental impacts from the international fleet of ships: the contribution from major ship types and ports, Atmos. Chem. Phys., 9, 2171-2194, 2009, http://www.atmos-chem-phys.net/9/2171/2009/.

Davis, D. D., Grodzinsky, G., Kasibhatla, P., Crawford, J., Chen, G., Liu, S., Bandy, A., Thornton, D., Guan, H., and Sandholm, S.: Impact of ship emissions on marine boundary layer $\mathrm{NO}_{\mathrm{x}}$ and $\mathrm{SO}_{2}$ distributions over the Pacific Basin, Geophys. Res. Lett., 28(2), 235-238, 2001.

de Meij, A., Krol, M., Dentener, F., Vignati, E., Cuvelier, C., and Thunis, P.: The sensitivity of aerosol in Europe to two different emission inventories and temporal distribution of emissions, Atmos. Chem. Phys., 6, 4287-4309, 2006,

http://www.atmos-chem-phys.net/6/4287/2006/.

Deniz, C. and Durmusoĝlu, Y.: Estimating shipping emissions in the region of the Sea of Marmara, Turkey, Sci. Total Environ., 390(1), 255-261, 2008.

Derwent, R., Stevenson, D. S., Doherty, R. M, Collins, W. J., Sanderson, M. G., Amann, M., and Dentener, F.: The contribution from ship emissions to air quality and acid deposition in Europe, Ambio, 34, 54-59, 2005.

Devasthale, A., Krüger, O., and Graß1, H.: Impact of ship emissions on cloud properties over coastal areas, Geophys. Res. Lett., 33, L02811, doi:10.1029/2005GL024470, 2006.

Endresen, Ø., Sørgård, E., Sundet, J., Dalsøren, S., Isaksen, I., Berglen, T., and Gravir, G.: Emissions from international sea transport and environmental impact,J. Geophys. Res., 108, 4560, doi:10.1029/2002JD002898, 2003.

Eyring, V., Koehler, H. W., van Aardenne, J., and Lauer, A.: Emissions from international shipping: 1. The last 50 years, J. Geophys. Res., 110(D17), D17305, doi:10.1029/2004JD005619, 2005.

Eyring, V., Stevenson, D. S., Lauer, A., Dentener, F. J., Butler, T., Collins, W. J., Ellingsen, K., Gauss, M., Hauglustaine, D. A., Isaksen, I. S. A., Lawrence, M. G., Richter, A., Rodriguez, J. M., Sanderson, M., Strahan, S. E., Sudo, K., Szopa, S., van Noije, T. P. C., and Wild, O.: Multi-model simulations of the impact of international shipping on Atmospheric Chemistry and Climate in 2000 and 2030, Atmos. Chem. Phys., 7, 757-780, 2007, http://www.atmos-chem-phys.net/7/757/2007/.

Fjaeraa, A. M. and Hjellbrekke, A.-G.: Ozone measurements 2006, EMEP/CCC-Report 2/2008, EMEP (European Monitoring and Evaluation Programme), Kjeller, Norwegian Institute for Air Research, Norway, online available at: http://tarantula.nilu.no/ projects/ccc/emepdata.html, last access: 10 January 2008, 2008.

Franke, K., Richter, A., Bovensmann, H., Eyring, V., Jöckel, P., and Burrows, J. P.: Ship emitted NO2 in the Indian Ocean: comparison of model results with satellite data, Atmos. Chem. Phys. Discuss., 8, 15997-16025, 2008,

http://www.atmos-chem-phys-discuss.net/8/15997/2008/.

Ganzeveld, L. and Lelieveld, J.: Dry deposition parameterization in a chemistry general circulation model and its influence on the distribution of reactive trace gases, J. Geophys. Res., 100, 20999-921012, 1995.

Gerasopoulos, E., Kouvarakis, G., Vrekoussis, M., Kanakidou, M., 
and Mihalopoulos, N.: Ozone variability in the marine boundary layer of the eastern Mediterranean based on 7-year observations, J. Geophys. Res., 110, D15309, doi:10.1029/2005JD005991, 2005.

Gery, M. W., Whitten, G. Z., and Killus, J. P.: Development and testing of the CBM-IV for urban and regional modelling, US EPA, Research Triangle Park EPA-600/3-88-012, 1989a.

Gery, M. W., Whitten, G. Z., Killus, J. P., and Dodge, M. C.: A photochemical kinetics mechanism for urban and regional scale computer modeling, J. Geophys. Res., 94(D10), 12925-12956, 1989b.

Ginoux, P., Chin, M., Tegen, I., Prospero, J. M., Holben, B., Dubovik, O., and Lin, S.-J.: Sources and distributions of dust aerosols simulated with the GOCART model, J. Geophys. Res., 106(D17), 20255-20273, 2001.

Ginoux, P., Prospero, J. M., Torres, O., and Chin, M.: Long-term simulation of global dust distribution with the GOCART model: Correlation with North Atlantic Oscillation, Environ. Modell. Softw., 19(2), 113-128, 2004.

Gong, S. L., Barrie, L. A., Blanchet, J. P., von Salzen, K., Lohmann, U., Lesins, G., Spacek, L., Zhang, L. M., Girard, E., Lin, H., Leaitch, R., Leighton, H., Chylek, P., and Huang, P.: Canadian Aerosol Module: A size-segregated simulation of atmospheric aerosol processes for climate and air quality models 1. Module development, J. Geophys. Res.-Atmos., 108, 4007, doi:10.1029/2001JD002002, 2003.

Granier, C., Niemeier, U., Jungclaus, J. H., Emmons, L., Hess, P., Lamarque, J. F., Walters, S., and Brasseur, G. P.: Ozone Pollution from Future Ship Traffic in the Arctic Northern Passages, Geophys. Res. Lett., L13807, doi:10.1029/2006GL026180, 2006.

Guenther, A., Hewitt, C. N., Erickson, D., Fall, R., Geron, C., Graedel, T., Harley, P., Klinger, L., Lerdau, M., McKay, W., Pierce, T., Scholes, B., Steinbrecher, R. Tallamraju, R., Taylor, J., and Zimmerman, P.: A global model of natural volatile organic compound emissions, J. Geophys. Res., 100, 8873-8892, 1995.

Dentener, F., Kinne, S., Bond, T., Boucher, O., Cofala, J., Generoso, S., Ginoux, P., Gong, S., Hoelzemann, J. J., Ito, A., Marelli, L., Penner, J. E., Putaud, J.-P., Textor, C., Schulz, M., van der Werf, G. R., and Wilson, J.: Emissions of primary aerosol and precursor gases in the years 2000 and 1750 prescribed data-sets for AeroCom, Atmos. Chem. Phys., 6, 4321-4344, 2006, http://www.atmos-chem-phys.net/6/4321/2006/.

Halmer, M. M. and Schmincke, H.-U.: VGIS (Volcanic Gas Input into the Stratosphere), AGU 2000 Fall Meeting, San Francisco, California, USA, 15-19 December 2000.

Halmer, M. M., Schmincke, H.-U., and Graf, H. F.: The annual volcanic gas input into the atmosphere, in particular into the stratosphere: a global data set for the past 100 years, J. Volcanol. Geoth. Res., 115, 511-528, 2002.

Hertel, O., Berkowicz, R., Christensen, J., and Hov, O.: Test of two numerical schemes for use in atmospheric transport-chemistry models, Atmos. Environ., 27, 2591-2611, 1993.

Houweling, S., Dentener, F., and Lelieveld, J.: The impact of nonmethane hydrocarbon compounds on tropospheric photochemistry, J. Geophys. Res., 103, 10673-10696, 1998.

IMO: IMO Newsroom, Press Briefings, Briefing 46, 10/10/2008, online available at: http://www.imo.org/Newsroom/mainframe. asp?topic_id=1709\\&doc_id=10262, 2008.
Jeong, C. H., Hopke, P. K., Kim, E., and Lee, D. W.: The comparison between thermal-optical transmittance elemental carbon and Aethalometer black carbon measured at multiple monitoring sites, Atmos. Environ., 38, 5193-5204, 2004.

Kasibhatla, P., Levy II, H., Moxim, W. J., Pandis, S. N., Corbett, J. J., Peterson, M. C., Honrath, R. E., Frost, G. J., Knapp, K., Parrish, D. D., and Ryersont, T. B.: Do emissions from ships have a significant impact on concentrations of nitrogen oxides in the marine boundary layer?, Geophys. Res. Lett., 27(15), 22292232, 2000.

Kinne, S., Schulz, M., Textor, C., Guibert, S., Balkanski, Y., Bauer, S. E., Berntsen, T., Berglen, T. F., Boucher, O., Chin, M., Collins, W., Dentener, F., Diehl, T., Easter, R., Feichter, J., Fillmore, D., Ghan, S., Ginoux, P., Gong, S., Grini, A., Hendricks, J., Herzog, M., Horowitz, L., Isaksen, I., Iversen, T., Kirkevåg, A., Kloster, S., Koch, D., Kristjansson, J. E., Krol, M., Lauer, A., Lamarque, J. F., Lesins, G., Liu, X., Lohmann, U., Montanaro, V., Myhre, G., Penner, J., Pitari, G., Reddy, S., Seland, O., Stier, P., Takemura, T., and Tie, X.: An AeroCom initial assessment - optical properties in aerosol component modules of global models, Atmos. Chem. Phys., 6, 1815-1834, 2006,

http://www.atmos-chem-phys.net/6/1815/2006/.

Kouvarakis, G., Tsigaridis, K., Kanakidou, M., and Mihalopous, N.: Temporal variations of surface regional background ozone over Crete Island in the southeast Mediterranean, J. Geophys. Res., 105(D4), 4399-4407, 2000.

Krol, M., Houweling, S., Bregman, B., van den Broek, M., Segers, A., van Velthoven, P., Peters, W., Dentener, F., and Bergamaschi, P.: The two-way nested global chemistry-transport zoom model TM5: algorithm and applications, Atmos. Chem. Phys., 5, 417432, 2005, http://www.atmos-chem-phys.net/5/417/2005/.

Lack, D., Lerner, B., Granier, C., Baynard, T., Lovejoy, E., Massoli, P., Ravishankara, A. R., and Williams, E.: Light absorbing carbon emissions from commercial shipping, Geophys. Res. Lett., 35, L13815, doi:10.1029/2008GL033906, 2008.

Lack, D., Corbett, J. J., Onasch, T., Lerner, B., Massoli, P., Quinn, P. K., Bates, T. S., Covert, D. S., Coffman, D., Sierau, B., Herndon, S., Allan, J., Baynard, T., Lovejoy, E., Ravishankara, A. R., and Williams, E.: articulate emissions from commercial shipping: Chemical, physical, and optical properties, Geophys. Res. Lett., 114, D00F04, doi:10.1029/2008JD011300, 2009.

Lauer, A., Eyring, V., Hendricks, J., Jöckel, P., and Lohmann, U.: Global model simulations of the impact of ocean-going ships on aerosols, clouds, and the radiation budget, Atmos. Chem. Phys., 7, 5061-5079, 2007, http://www.atmos-chem-phys.net/7/5061/2007/.

Lawrence, M. G. and Crutzen, P. J.: Influence of $\mathrm{NO}_{\mathrm{x}}$ emissions form ships on tropospheric photochemistry and climate, Nature, 402, 167-170, 1999.

Lelieveld, J. and Dentener, F. J.: What controls tropospheric ozone?, J. Geophys. Res., 105(D3), 3531-3551, 2000.

Lelieveld, J., Berresheim, H., Borrmann, S., Crutzen, P. J., Dentener, F. J., Fischer, H., Feichter, J.,Flatau, P. J., Heland, J., Holzinger, R., Korrmann, R., Lawrence, M. G., Levin, Z., Markowicz, K. M., Mihalopoulos, N., Minikin, A., Ramanathan, V., De Reus, M., Roelofs, G. J., Scheeren, H. A., Sciare, J., Schlager, H., Schultz, M., Siegmund, P., Steil, B., Stephanou, E. G., Stier, P., Traub, M., Warneke, C., Williams, J., and Ziereis, H.: Global air pollution crossroads over the Mediterranean, Sci- 
ence, 298, 5594, 794-799, 2002.

Lloyd's Maritime Information System (LMIS), he Lloyd's Maritime Database [CD-ROM], Lloyd's Register-Fairplay Ltd., London, 2002.

LMIU(Lloyd's Marine Intelligence Unit): Extract from the vessel movement database 1999 (January, April, July, October), 2000.

LRF, Lloyd's Register Fairplay: Extract from the world fleet database (all civil ocean-going cargo and passenger ships above or equal to $100 \mathrm{GT}$ ), Redhill, UK, 2004.

Marmer, E. and Langmann, B.: Impact of ship emissions on Mediterranean summertime pollution and climate: A regional model study, Atmos. Environ., 39, 4659-4669, 2005.

Olivier, J. G. J., Van Aardenne, J. A., Dentener, F., Pagliari, V., Ganzeveld, L. N., and Peters, J. A. H. W.: Recent trends in global greenhouse gas emissions: regional trends 1970-2000 and spatial distribution of key sources in 2000, Environ. Sci., 2(2-3), 81-99, doi:10.1080/15693430500400345, 2005.

Palumbo, I., Kucera, J., Barbosa, P., O’Brien, V. W., and Valentini, R.: Using SEVIRI geostationary imagery for active fires analysis and burned biomass estimation: A case study in a Mediterranean ecosystem, Forest Ecol. Manag., 234, S222, ISSN 0378-1127, doi:10.1016/j.foreco.2006.08.249, 2006.

Papadimas, C. D., Hatzianastassiou, N., Mihalopoulos, N., Querol, X., and Vardavas, I.: Spatial and temporal variability in aerosol properties over the Mediterranean basin based on 6-year (20002006) MODIS data, J. Geophys. Res.-Atmos., 113 , D11205, doi:10.1029/2007JD009189, 2008.

Peters, W., Krol, M. C., Dlugokencky, E. J., Dentener, F. J., Bergamaschi, P., Dutton, G., Velthoven, P. V., Miller, J. B., Bruhwiler, L., and Tans, P. P.: Toward regional-scale modeling using the two-way nested global model TM5: Characterization of transport using SF6, J. Geophys. Res.-Atmos., 109, D19314, doi:10.1029/2004JD005020, 2004.

Richter, A., Eyring, V., Burrows, J. P., Bovensmann, H., Lauer, A., Sierk, B., and Crutzen, P. J.: Satellite measurements of $\mathrm{NO}_{2}$ from international shipping emissions, Geophys. Res. Lett., 31, L23110, doi:10.1029/2004GL020822, 2004.

Sinha, P., Hobbs, P. V., Yokelson, R. J., Christian, T. J., Kirchstetter, T. W., and Bruintjes, R.: Emission of trace gases and particles from two ships in the southern Atlantic Ocean, Atmos. Environ., 37, 2139-2148, 2003.

Stern, N.: Stern Review on the Economics of Climate Change, HM Treasury, The Stationary Office, London, 2007.

Stevenson, D. S., Dentener, F. J., Schultz, M. G., Ellingsen, K., van Noije, T. P. C., Wild, O., Zeng, G., Amann, M., Atherton, C. S., Bell, N., Bergmann, D. J., Bey, I., Butler, T., Cofala, J., Collins, W. J., Derwent, R. G., Doherty, R. M., Drevet, J., Eskes, H. J., Fiore, A. M., Gauss, M., Hauglustaine, D. A., Horowitz, L. W., Isaksen, I. S. A., Krol, M. C., Lamarque, J.-F., Lawrence, M. G., Montanaro, V., Müller, J.-F., Pitari, G., Prather, M. J., Pyle, J. A., Rast, S., Rodriguez, J. M., Sanderson, M. G., Savage, N. H., Shindell, D. T., Strahan, S. E., Sudo, K., and Szopa, S.: Multimodel ensemble simulations of present-day and near-future tropospheric ozone. J. Geophys. Res., 111, D08301, doi:10.1029/2005JD006338, 2006.

Streets, D. G., Carmichael, G. R., and Arndt, R. L.: Sulfur dioxide emissions and sulfur deposition from international shipping in Asian waters, Atmos. Environ., 31(10), 1573-1582, 1997.

Streets, D. G., Bond, T. C., Carmichael, G. R., Fernandes, S.
D., Fu, Q., He, D., Klimont, Z., Nelson, S. M., Tsai, N. Y., Wang, M. Q., Woo, J.-H., and Yarber, K. F.: An inventory of gaseous and primary aerosol emissions in Asia in the year 2000, J. Geophys. Res., TRACE-P Special Issue, 108(D21), 8809, doi:10.1029/2002JD003093, 2003.

Strengers, B., Leemans, R., Eickhout, B., Vries, B., and Bouwman, L.: The land-use projections and resulting emissions in the IPCC SRES scenarios as simulated by the IMAGE 2.2 model, GeoJournal, 61(4), 381-393, doi:10.1007/s10708-004-5054-8, 2004

Textor, C., Schulz, M., Guibert, S., Kinne, S., Balkanski, Y., Bauer, S., Berntsen, T., Berglen, T., Boucher, O., Chin, M., Dentener, F., Diehl, T., Easter, R., Feichter, H., Fillmore, D., Ghan, S., Ginoux, P., Gong, S., Grini, A., Hendricks, J., Horowitz, L., Huang, P., Isaksen, I., Iversen, I., Kloster, S., Koch, D., Kirkevåg, A., Kristjansson, J. E., Krol, M., Lauer, A., Lamarque, J. F., Liu, X., Montanaro, V., Myhre, G., Penner, J., Pitari, G., Reddy, S., Seland, Ø., Stier, P., Takemura, T., and Tie, X.: Analysis and quantification of the diversities of aerosol life cycles within AeroCom, Atmos. Chem. Phys., 6, 1777-1813, 2006,

http://www.atmos-chem-phys.net/6/1777/2006/.

van der Werf, G. R., Randerson, J. T., Collatz, G. J., Giglio, L., Kasibhatla, P. S., Arellano Jr., A. F., Olsen, S. C., and Kasischke, E. S.: Continental scale partitioning of fire emissions during the 1997 to $2001 \mathrm{El} \mathrm{Niño/La} \mathrm{Niña} \mathrm{period,} \mathrm{Science,} \mathrm{303,} 73$ 76, 2004.

van Loon, M., Vautard, R., Schaap, M., Bergstrom, R., Bessagnet, B., Brandt, J., Builtjes, P. J. H., Christensen, J. H., Cuvelier, C., Graff, A., Jonson, J. E., Krol, M., Langner, J.,Roberts, P., Rouil, L., Stern, R., Tarrason, L., Thunis, P., Vignati, E., White, L., andWind, P.: Evaluation of long-term ozone simulations from seven regional air quality models and their ensemble, Atmospheric Environment, 41(10), 2083-2097, 2007.

Velchev, K., Cavalli, F., Hjorth, J., Marmer, E., Vignati, E., Dentener, F., and Raes, F.: Ozone over the Western Mediterranean Sea - results from two year fo shipborne measurments, in preparation, 2009.

Vestreng, V., Mareckova, K., Kakareka, S., Malchykhina, A., and Kukharchyk, T.: Inventory Review 2007; Emission Data reported to LRTAP Convention and NEC Directive, MSC-W Technical Report 1/07, The Norwegian Meteorological Institute, Oslo, Norway, 2007.

Vignati, E., Facchini, M. C., Rinaldi, M., Kanakidou, M., Myriokefalitakis, S., Scannell, C., Sciare, J., Pio, C., Dentener, F., and O'Dowd, C.: Primary insoluble organic aerosols from the sea: impact at global scale, in preparation, 2009.

Wang, C., Corbett, J. J., and Firestone, J.: Improving Spatial Representation of Global Ship Emissions Inventories, Environ. Sci Technol., 42, 193-199, 2008.

Whall, C., Cooper, D., Archer, K., Twigger, L., Thurston, N., Ockwell, D., McIntyre, A., and Ritchie, A.: Quantification of emissions from ships associated with ship movements between ports in the European Community, European commission final report, Entec UK Limited, Winsor House, Gadbrook Business Centre, Gadbrook Read, Norwitch, Cheshire CW9 7NT, UK, 2002.

Whall, C. and Stavrakaki, A.: Ship Emission Inventories, Presentation at the Task Force on Emission Inventories and Projections (TFEIP) in Tallinn, 28 May 2008.

Yienger, J. and Levy, H.: Global inventory of soil-biogenic $\mathrm{NO}_{\mathrm{x}}$ emissions, J. Geophys. Res., 100, 11447-11464, 1995. 